\title{
UNA EPIFANÍA DE LA PATRIA: «GALICIA. REVISTA UNIVERSAL DE ESTE REINO» (1860-65)
}

\author{
Por \\ MARÍA ROSA SAURÍN DE LA IGLESIA
}

Con constancia y regularidad insólitas para una época de publicaciones efímeras, esta revista difundió durante seis años actitudes que son una aportación temprana al problema de España antes de la crisis finisecular. Significativo es su nacimiento en La Coruña, cuyo dinamismo y desarrollo rivalizaban con el poderoso legado histórico de Santiago y la convertían en guía de la Galicia moderna. La revista se propone combatir los prejuicios que hacían de Galicia la imagen de la esterilidad y la rudeza y para ello muestra los gérmenes de vitalidad existentes a despecho del aislamiento del país y de la desastrosa coyuntura. Ansiosa de demostrar al mundo su riqueza de talentos, instituciones culturales, bellezas naturales y artísticas, historia, arte y letras, convoca a propios y extraños con el ambicioso objetivo de lograr un retrato verídico del país más olvidado.

La meditación sobre las causas del atraso de Galicia llega al hilo del momento histórico en que la homogeneidad territorial, social y lingüística impuesta por el liberalismo triunfante no genera el esplendor material previsto. Si en 1812 la igualdad jurídica de regiones e individuos había representado un avance, cincuenta años después decepciona y parece allanamiento insensato el centralismo que mide por el mismo rasero realidades peninsulares muy diversas. Además de someter las culturas periféricas a la dominante, la aplicación de aquella lógica dieciochesca redujo more 
geometrico los límites geográficos del Antiguo Reino de Galicia y alteró su estructura. Desgobierno, malas cosechas y efectos de la Desamortización acabaron de herirlo de muerte sin que nada atenuase la degradación ni el miserable vegetar de aquel país dejado de la mano de Dios. En tanto, su omnipresente proletariado hacía de él «la imbécil China de España», «el Senegal de Europa que surte los mercados que bañan las ondas del Plata $\rangle^{1}$. No extraña que la percepción de la existencia local adquiriera por entonces rasgos emotivos peculiares -que perpetúan en la expresión común las connotaciones insultantes del epíteto gallego-, con momentos de altísima tensión e incluso amagos insurreccionales.

Al mediar el siglo se enciende la esperanza de conjurar tanta desgracia y de ponerse al paso con la modernidad. Son los hombres de letras quienes se niegan a aceptar como fatalidades las servidumbres creadas por la sociedad y quienes se aplican a borrar aquel marchamo de inferioridad material y moral ${ }^{2}$. Ellos elaboran un programa regenerador para el mundo marginado en que vivían y en sus reflexiones desentierran una cultura galaica con señas de identidad propias, merecedora de respeto y dignidad. Enfervorizados con un patriotismo de nuevo cuño emprenden una tarea que descubre valores alternativos en todas las manifestaciones de la vida local y les comunica protagonismo inusitado convirtiéndolas en mucho más que objeto de ejercicio estético puro y simple. Tanto como para deducir de allí un nuevo código ético cara al futuro.

\section{PRECEDENTES}

La fórmula publicística de esta revista recoge y perfecciona incitaciones que quince años antes habían movilizado a la juventud santiaguesa contra la imagen denigrante de su patria. En aquel momento la lección de Ramón de la Sagra y de Lamennais impregnaba la prensa con ansias de regeneración social preparando la sublevación contra el sistema fiscal que

\footnotetext{
${ }^{1}$ Pelayo CATOIRA, Discurso pronunciado por D ... en la inauguración del Ateneo el dia 2 del actual, en «El Ateneo», 6.X.1859.

${ }^{2}$ Cfr. M. R. SAURIN DE LA IGLESIA, Apuntes y documentos para una historia de Galicia en el siglo XIX, Diputación Provincial de La Coruña, 1977.
}

"CUADERnOS DE ESTUdiOs GALLEGOS", Tomo XLVII, Fascículo 113, Santiago 2000. 
atenazaba a Galicia y contra la oligarquía que lo aplicaba ${ }^{3}$. La condena del fiscalismo foráneo trajo a primer plano la exaltación de la «excentralización», con su poder decisorio local. Y como aquel «provincialismo» suponía ya un grado más elevado de organización que el mero ejercicio de la publicística cultural, su fracaso, además de un doloroso escarmiento, produjo una cautela que en lo sucesivo iría disfrazada de apoliticismo. De los periódicos de entonces interesa «La Aurora de Galicia», disconforme pero no extremista, donde se estrenó en 1845 el futuro director de «Galicia» (=GRUR), y la «Revista de Galicia», de 1850, donde maduraron sus intereses galaicos ${ }^{4}$.

La desazón persistente sigue siendo sentida reflexión que enlaza a escritores comprometidos en el primer renacimiento cultural con los de la generación siguiente: las firmas de los Camino, José María Gil, Díaz de Robles, Añón, Vicetto, Ramón de la Sagra, Neyra de Mosquera, presentes en GRUR, evocan el clima en que se había gestado el descubrimiento de Galicia como problema. Y la percepción dolorosa de la ruina del país, «tinieblas horribles de una noche sin luz y sin estrellas» ${ }^{5}$, impulsa a afrontar una vez más el atraso de Galicia, escandaloso dadas sus posibilidades geofísicas, con argumentos que evidencian cómo insignificancia cultural

\footnotetext{
${ }^{3}$ Cfr. Xosé Ramón BARREIRO FERNÁNDEZ, El levantamiento de 1846 y el nacimiento del galleguismo, Pico Sacro, Santiago de Compostela, 1977, pp. 83-97; Ascensión CAMBRÓN INFANTE, El socialismo racional de Ramón de la Sagra, Diputación Provincial de La Coruña, 1989, pp. 123-128.

${ }^{4}$ Las líneas generales de esta última revista se plantean con energía a partir de la primera entrega: mientras Europa presencia un desarrollo incomparable desde principios del XIX «España no tuvo tiempo ni para conocer[lo]» por lo que urge crear periódicos que lo promuevan, diferentes para cada parte del país; «En varias provincias aparecieron ya publicaciones que están prestando inmensas utilidades, y la nuestra, que es la que más las requiere, carece de ellas hasta ahora»; el deber de los hijos de este país tan hermoso como desconocido es mostrarle los caminos a seguir, educar y revisar la legislación para favorecer intereses agrícolas e industriales; la agricultura, su primera riqueza, debe abastecer al mercado español y extranjero una vez que el labrador haya sido adoctrinado; la historia de Galicia no existe, hay que «sacar del polvo manuscritos, arrancar a los viejos castillos la capa de hiedra que los asfixia, reconstruir tradiciones y recuerdos, levantar monumento en gloria de la patria»; «Tales son las materias de que debe tratar un periódico en Galicia»: Jose $\mathrm{M}^{\mathrm{a}}$ GIL, Introducción, en «Revista de Galicia. Periódico de sus intereses materiales, morales e intelectuales», Santiago $1^{\circ}$.VI.1850, pp. 1-11

${ }^{5}$ Introducción, GRUR, I, $1^{\circ}$.X.1860, $\mathrm{n}^{\circ} 1$, p. 2 . En adelante se suprimen las siglas; el número romano remite al año de la revista.
}

"CUADERNOS DE ESTUDIOS GALLEGOS", Tomo XLVII, Fascículo 113, Santiago 2000. 
y aislamiento son causa y efecto a la vez de la marginación. Pero en contraste con los revolucionarios de antaño, nueva es la propensión a adjudicarle el Estado la consecución de las metas frustradas en 1846. Una gran esperanza en su intervención induce a exhibir ante España entera los méritos de una tierra que por sí solos habrían de desmentir cualquier prejuicio.

Al renovar el proceso de concienciación varias veces detenido la nueva revista se convierte en hogar espiritual para todos los que sentían el dolor de Galicia y en unión con los gallegos de Ultramar pretendían alumbrar una nueva identidad gallega. Su empeño no es propiamente político aunque ambicione constituir un estado de opinión y en parte lo logre gracias a su larga duración. Aun manteniéndose fuera del juego del poder supo hacer de los problemas locales un tema de atención urgente en el ámbito de las preocupaciones nacionales ${ }^{6}$, dio hondura y sistema a las cavilaciones sobre aquel «país dejado de la mano de Dios» ${ }^{7}$ y comunicó al mundo provincial conciencia de sí sacándolo de su letargo. Todo en sus páginas se ha de leer por eso no como la historia de un resentimiento sino más bien como la crónica de un despertar, contribución positiva al proceso de creación de la cultura colectiva que define lo español.

Si lo característico de la prensa anterior había sido el uso exclusivo del castellano, se tiende ahora a institucionalizar la lengua local. Por más que en el planteamiento general sobreviva el referente ilustrado ${ }^{8}$, muy viva es

\footnotetext{
${ }^{6}$ Antonio Santiago Somoza a F. de la Iglesia, Madrid, 8.XII.1861, anuncia el interés hacia la revista de Ramón de la Sagra y la Avellaneda: RAG, Donación de la Iglesia, Caja 97. Las conexiones con el «Diario de la Marina» aseguraban un amplio auditorio antillano.

${ }^{7}$ El castillo de la Rocha, VI, $1^{\circ}$.IV.1865, n 7, p. 108; A. de la IGLESIA, Puente Don Alonso y monasterio de San Justo, IV, $1^{\circ}$.X.1863, $\mathrm{n}^{\circ} 19$, pp. 220-221.

${ }^{8}$ V. como ejemplo la circular a los maestros rurales: «Señor Maestro de / Muy Señor mío y amigo: Por el correo recibirá V. algunos prospectos como el adjunto de la publicación que acabo de fundar con el título de «Galicia». A cada una de las entregas tengo pensado acompañar un suplemento en que, por un precio módico, se enteren los maestros suscritores de los asuntos que más les conciernen en el ramo de la enseñanza. Reconociendo el amor que tanto V. como los demás maestros del distrito, profesan al país, no dudo que acogerán esta publicación no sólo como suscritores, sino que pondrán en juego sus relaciones particulares, a fin de que la suscrición se propague todo lo posible; a cuyo efecto deseo que hable V. en mi nombre a los compañeros, que tendrán la presente como si fuese a ellos dirigida, y nombro a V. desde luego encargado de la comisión de suscriciones del distrito, y en tal concepto irán remitidas a V. todas las entregas de los suscritores que ahí se reúnan con lo cual se ahorran gastos a los mismos, cuidando V. de que en
} 
la herencia romántica, que no se limita -según el famoso paradigma de «El Artista»-a despertar conciencias adormecidas o a avivar el gusto por las bellas artes con la simple descripción de monumentos, biografías de grandes hombres o amena literatura sino que especifica su misión en proyectos de reforma moral y material que atañen a una sociedad entera y no sólo a sus clases elevadas?.

\section{LOS EDITORES}

Responsables de la publicación son Antonio y Francisco María de la Iglesia, santiagueses avecindados en La Coruña (13.I.1820-26.IV.1892 y 2.II.1829-5.IV.1897, respectivamente). Poco o mal conocidos, al igual que tantos personajes de esta época, urge una biografía moderna que defina su trayectoria intelectual y su profundo engagement ${ }^{10}$. Antonio da sus primeros pasos como becario de la Diputación coruñesa en la recién creada Escuela Normal Central de Madrid, estimable logro educativo de los liberales en el poder según los ideales de Gil y Zárate y de Pablo Montesino, que de la emigración habían traído una saludable apertura hacia inspiraciones modernas. De la creación de seminarios de maestros al estilo de los países desarrollados se esperaba la resolución del penoso retraso cultural

seguida las reciban ellos en propia mano. / Al mismo tiempo, ruego a VV. todos, me envíen una relación de las cosas notables que cada uno tenga en su distrito escolar, como son ferias, romerías, santuarios, ermitas, iglesias parroquiales con lo más digno de atención que contengan ya por su antigüedad, ya por su mérito artístico. También conviene en la relación lo de baños, aguas minerales, producciones de la tierra, clases de árboles, arbustos, yerbas y plantas, modo de cultivar, montes y ríos principales, número de casas y habitantes de cada aldea, etc, etc y las industrias que se conozcan. Los Sres. párrocos y caballeros que haya, auxiliarán con inteligencia en esos datos y VV. en mi nombre les ofrecerán las columnas del periódico para cuanto se sirvan suministrar en honor del país. / Esto me presenta la gustosa oportunidad de ofrecerme de V. y compañeros afectísimo y S.S.Q.B.S.M. / Coruña $1^{\circ}$ de Setiembre de 1860» (Archivo de laA.). La revista publicaba un suplemento de instrucción pública: v. SOTO FREIRE, La imprenta en Galicia, El Círculo de las Artes, Lugo, 1982, a cargo de X. R. Barreiro Fernández, p.58.

${ }^{9}$ Cfr. I, $1^{\circ} . X .1860$, $\mathrm{n}^{\circ} 1$, p. 1 , Introducción.

${ }^{10} \mathrm{Cfr}$. D. Antonio de la Iglesia González, en Suplemento al ${ }^{\circ} \mathrm{V}$ de «La Ilustración Coruñesa. Ciencias, Letras, Artes», I, 15.VI.1886, pp. I-IV; Santiagueses ilustres. Don Antonio de la Iglesia González, escritor, en «El Eco de Santiago», 5 y 6.XI.1901.

"CUADERNOS DE ESTUDIOS GALLEGOS", Tomo XLVII, Fascículo 113, Santiago 2000. 
de España ${ }^{11}$, y aunque la penuria de recursos aplazó su establecimiento, cinco años más tạrde la inauguración de la Escuela Normal Central prometía la equiparación con Europa ${ }^{12}$. De la primera promoción de esa institución renovadora sale Antonio para regresar a su provincia en 1844 con el encargo de hacer fructificar aquella semilla fundando la Escuela Normal local. Preparación profesional aparte, la estancia en la Corte le revela novedades que nunca habría conocido en su tierra natal. Y no sólo desde el punto de vista cultural, porque en Madrid descubre tambien con toda crudeza la consideración tercermundista en que eran tenidos los gallegos. La sorpresa de descubrirse como un ser de excepción en un ambiente dominado por prejuicios es experiencia poco grata que marcará su conciencia local y que enriquece el sentido de toda su actividad ${ }^{13}$.

Mientras estudia y frecuenta tertulias de paisanos afincados en la Corte - los Gil, por ejemplo, colaboradores de «El Arpa del Creyente» ${ }^{14}-$,

\footnotetext{
${ }^{11}$ La formulación de ese pensamiento se encuentra en el decreto de 31.VIII.1834.

${ }^{12} \mathrm{Cfr}$. Antonio GIL DE ZÁRATE, De la instrucción pública en España, Imprenta del Colegio de sordo-mudos, Madrid, 1855, cap. III, De las Escuelas normales, edición facsímil Pentalfa, Oviedo, 1995; Joaquín SAMA, Don Pablo Montesino: La instrucción primaria en 1808 y su desarrollo posterior, en «Boletín de la Institución Libre de Enseñanza», $n^{\circ} 271$, XII, 1888, pp. 133-139; id., El concepto de educación según Montesino, id., $n^{\circ}$ 280, XII, 1888, pp. 241-245; J. RUIZ BERRIO, Un reformador español: Pablo Montesino. En su segundo centenario, en «Escuela Española», 2564, 1981, 6.

${ }^{13} \mathrm{C}$ fr. la confesión autobiográfica Hoja de un diario, «La Aurora de Galicia», 16. V. $1845, n^{\circ} 2$, p. 16; reproducida en SAURIN DE LA IGLESIA, Apuntes ..., cit., p. 61).

${ }^{14}$ Sus desahogos epistolares tras el regreso a Santiago de A.de la I. revelan el talante y malestar de la juventud engagé: «¡Pobre Galicia! Has visto caer a los golpes del hacha de la revolución tus sombrías e inmensas robledas; el huracán político ha llevado tus riquezas al suelo estranjero como leves pajillas; tus puertos fueron traidoramente abiertos a los algodones de allende los mares y a los lienzos que la astuta Albión miente tuyos; tus mejores hijos, cansados de servir de escala a mezquinas ambiciones, o despreciados por envidiosos compatriotas, huyeron lejos de ti abandonandote a tu desventura; tus patricios han enmudecido en el Congreso y en el Senado, o si hablaron fue sólo para tu daño y para su provecho; Galicia ¿qué va a ser de ti? Y si ahora, ciega a lo que pasa en el mundo, desoyendo la voz de la Europa, te lanzas loca en brazos de nuevas sediciones, para que te engrandezcan los que claman ;igualdad! y te respeten los que gritan ;libertad! no mereces con justicia verte hundida en el seco polvo que levantan en las llanuras cien y cien mil caballos, y ver manchada tu frente con la asquerosa sangre de las batallas; y tu manto de verde terciopelo matizado de flores, todo enlodado y hecho trizas, y tu corona fabricada con el purísimo oro del Sil y realzada con los topacios nacidos entre el granito de tus montañas y las perlas habidas en el abrigados senos de tus mares, conver-
} 
presencia la efervescencia de la prensa y asimila los fundamentos del movimiento historiográfico moderno. Es decir, aprende a encuadrar las aspiraciones nacientes del prenacionalismo gallego en las coordenadas europeas de su tiempo. Aunque el estado actual de la investigación no permita precisar más, ese periodo de estudios hubo de revelarle ideas sobre la regeneración de España a través de la educación que flotaban en el ambiente y que llegarían a su auge con el krausismo. No es de este lugar reconstruir los contactos con personas y métodos comprometidos en aquella misión pedagógica total pero convendrá recordar cómo ese caldo de cultivo, además de producir una hornada de buenos educadores y forjadores de hombres, originó también la revalorización de la mujer que aspiraba a sacarla del medio tradicional y a dotarla de una profesión ${ }^{15}$.

Una vez en su tierra Antonio interviene en la prensa de perfil literario haciendo sus primeras armas en «La Aurora de Galicia», dentro de un confesionalismo tradicional sin extremismos políticos, y en 1850 en la «Revista de Galicia». En adelante alternará constantemente sus tareas docentes y de inspección escolar con el periodismo cultural, compartiendo ese itinerario, ya en La Coruña, con su hermano Francisco. Significativo es que se asocie desde el momento fundacional al Circo de Artesanos de La Coruña con su lema recreación e ilustración y su intenso empeño asociativo $^{16}$. Las bases sentadas en aquellas primicias publicísticas fueron inspiración indudable para GRUR, donde se transparenta un entramado análogo $0^{17}$. La obra sucesiva, ligada siempre a la prensa, es cientificamente

tida en una corona de abrojos que punze dolorosamente la más hermosa de las cabezas españolas. ¡Ah, Galicia! ¡Galicia! ¡Quien pudiera presentarte los que crees órganos de opinión pública! Eso sólo bastaría para que no buscases en la política los caminos de tu prosperidad!»: José María Gil a Antonio de la Iglesia, Madrid, 4.III.1844, f. 3, en RAG, Donación de la Iglesia, caja 97.

${ }^{15}$ Así las escuelas dominicales de Fernando de Castro y las iniciativas de C. Arenal: v. Yvonne TURIN, L'éducation et l'école en Espagne de 1874 a 1902, Presses Universitaires de France, 1959, pp. 269 y sigs.; cfr. A. de la IGLESIA, La universidad de las mujeres, VI, $1^{\circ} . X .1865, n^{\circ} 19$, pp. 294-297.

${ }^{16} \mathrm{Cfr}$. «El Faro Coruñés. Periódico artístico y literario», 31.III.1847, n 14 , pp. 1 y 8.

${ }^{17}$ Datos sobre las dos publicaciones cit. en Pablo PÉREZ COSTANTI, Historia del periodismo santiagués, Santiago, Escuela Tip. Municipal, 1905, ed. facsímil de José Luis Cabo, Ediciós do Castro,A Coruña, 1992, pp. 105-107; cfr. Manuel SOTO FREIRE, op. cit., p. 108.

"CUADERNOS DE ESTUDIOS GALLEGOS", Tomo XLVII, Fascículo 113, Santiago 2000. 
heterogénea pero no por eso menos válida. Tenaz y fecundo aunque asistemático se revela, por ejemplo, el esfuerzo historiográfico de GRUR, alegato a favor de un nuevo modo de hacer historia. Si hasta aquel momento no había habido una historia de Galicia ahora se la hace surgir de las nieblas de la ignorancia. La larga vida de la revista permitió ir modelando la conciencia local a través de un relato histórico concerniente a todo lo que afectase al pasado y al ser de los gallegos. Dada la ambición de cambiar el insatisfactorio presente en vista de un futuro mejor, bajo esa luz se plantean toda clase de cuestiones relacionadas con la existencia no sólo de los gallegos, sino de la colectividad española ${ }^{18}$. Se abre así un capítulo importante en la génesis del concepto contemporáneo de España, proyectado hacia el futuro a partir del horizonte histórico del momento.

El aprendizaje del arte dé enseñar preparó aAntonio, entre otras cosas, para sacar partido de la observación de su tierra. Continuos desplazamientos como inspector de enseñanza primaria lo obligaron a múltiples contactos con distintas comarcas gallegas inspirando unas crónicas llenas de vida. Observando con ojos críticos un estado de cosas sumamente insatisfactorio no se resigna a la atonía genera ${ }^{19}$. Igual que otros jóvenes inquietos de toda España llega, como Costa, a la convicción de que la mitad del problema de España dependía de la pobreza, generadora de incultura. Su formación lo lleva a abordar el problema como educador, no como político. Cuando rastreando las señales de una dignidad remota y deseable las documenta desde el Medioevo, no formula teorías sobre el carácter gallego ni achaca las desdichas presentes a conflicto alguno de culturas; simplemente brinda a sus lectores esos estímulos aleccionadores que inspiran respeto hacia la patria y esperanzas de mejoría.

Habiendo iniciado su carrera entre el gobierno moderado y la Unión liberal huelga encarecer su circunspección. Una colección de «El Pensamiento de la Nación» existente en su biblioteca sugiere una mediación

\footnotetext{
${ }^{18} \mathrm{Cfr}$. Introducción cit.

${ }^{19} \mathrm{~V}$. su temprano planteamiento del problema de España como un problema de cultura en Discurso del Profesor D. A. de la I., Director de la Escuela Normal provincial de La Coruña y Catedrático de Retórica y Poética y de Historia en el Colegio de segunda enseñanza de la capital, en la inauguración solemne y primera apertura de estudios de este último establecimiento, el año 1847: III, 15.VIII.1862, nº 20, pp. 305-308.
}

"CUADERNOS DE ESTUDIOS GALLEGOS", Tomo XLVII, Fascículo 113, Santiago 2000. 
nada insignificante en la asunción del nuevo nacionalismo: Balmes era el divulgador e intérprete más atendible entonces de la justificación de los derechos de los pueblos y la valoración hecha por él de la unidad de Italia, su elogio de Pío IX y de O'Connell representaban una garantía para los bienpensantes ${ }^{20}$. Igual aprecio debió merecerle la obra de Cantú, con sus fervorosas incitaciones a un patriotismo liberal de nuevo cuño ${ }^{21}$. Pero como contrapartida no deja de llamar la atención en tan decidido defensor de los derechos de los pueblos la repetida invocación poética a la beligerancia en Marruecos. Para explicar esa contradicción cabe conjeturar posibles presiones del Ministerio sobre funcionarios siempre en un tris de quedar cesantes a cada cambio de gobierno, como acabó por sucederle a él mismo con la Restauración, a pesar de su meritoria labor de alfabetización rural. No hay que descartar la instrumentación política de las dotes poéticas, siguiendo convicciones ilustradas ${ }^{22}$.

La trayectoria de Francisco, el segundo de los hermanos de la Iglesia, revela una formación profesional análoga, conseguida en la recién creada Escuela Normal de La Coruña ${ }^{23}$, también como becario de la Diputación. Iniciada su carrera de maestro en La Coruña, con ella emparejó enseguida una intensa participación en la prensa local con la que consigue labrarse cierta reputación de poeta. Aunque carecemos de estudios actuales sobre

\footnotetext{
${ }^{20} \mathrm{Cfr}$. Miguel BATLLORI, Balmes e il Risorgimento italiano, en Gli spagnoli e l'Italia, Scheiwiller, Milano, 1997, pp. 29-38.

${ }^{21}$ Los nueve tomos de la archifamosa Historia universal figuran con el número 65 en la lista de libros donados por la viuda de Francisco de la Iglesia a la Biblioteca del Instituto de La Coruña: Catálogo de las obras donadas a la Biblioteca del Instituto Provincial de segunda enseñanza de la Coruña por la Vda. e hijos de D.F.M.de la I., 17.IV.1897 (Archivo de la A).

${ }^{22}$ La nota al pie de una hoja volante con una Canción a la guerra de Africa de su autoría -Coruña, 1860, Imprenta del Hospicio- dice: «Precio 4 cuartos: su producto a beneficio de la Guerra, a cuyo fin se hace propiedad de todos los Ayuntamientos, Gobiernos civiles y Autoridades superiores de España». Cfr. «O vello do Pico Sagro», publicación periódica de la que poseo los cinco primeros números, quizá los únicos, 3.III al 28.IV.1860, Imprenta do Hespicio Provincial, Coruña, 1860: el texto es un largo romance sobre la guerra de África; vuelve repetidamente sobre el tema en GRUR, en gallego y castellano.

${ }^{23}$ Cfr. Discursos pronunciados en la apertura de la Escuela Normal de Instrucción primaria de la provincia de La Coruña celebrada el día 2 de julio de 1845, La Coruña, Domingo Puga, 1845.
}

"CUADERNOS DE ESTUDIOS GALLEGOS", Tomo XLVII, Fascículo 113, Santiago 2000. 
esa actividad incansable en periódicos de perfil literario ${ }^{24}$ consta que en 1856 colaboraba con Timoteo Pombo y Antonio San Martín en «El Defensor de Galicia» ${ }^{25}$ y que en 1857 redactaba junto con Antonio y otros amigos entusiastas «El Fomento de Galicia. Periódico destinado exclusivamente al desarrollo de los intereses materiales del país». A partir del año siguiente dirige el «Diario de La Coruña. Periódico literario, científico e industrial» con su hermano Antonio como redactor ${ }^{26}$. El punto más alto de estos intereses lo señala la creación de GRUR, lo que no excluye que entre tanto sigan los dos hermanos escribiendo en «El Anunciador. Periódico consagrado al comercio, a la industria y a las artes $\rangle^{27}$.

Una regular fama rodeó a los de la Iglesia que lograron la consagración oficial a la manera de los poetas románticos, más que a través del libro con la lectura pública de sus obras y con la presencia constante en la prensa $^{28}$. A pesar del apreció de los contemporáneos, la abundante producción de ambos hermanos sigue hoy dispersa y sin estudiar ${ }^{29}$. Bastaría, a decir verdad, volver a poner en circulación esta revista para recobrar, junto a una parte importante de la obra de los dos hermanos, lo más granado del renacimiento cultural gallego. Sus páginas patentizan la lección y

${ }^{24}$ Cfr. Eugenio CARRÉ, D. F. de la I. G., en «Revista de Galicia», 11.IV.1897; D. F. $M$. de la I., poeta y escritor, en «El Eco de Santiago, $\mathrm{n}^{\circ} 1999,1901$, que contiene varios errores; Fr. Gumersindo PLACER, D. F. M. de la I.. Apuntes para su biografia, en «Boletín de la Real Academia Gallega», XXIV, n 220, 1‥XII.1930, pp.95-102; id., F. M. de la I., maestro y poeta gallego. Siglo XIX, en Suplemento de «Misión», n² 217, 1.XII.1938, pp. 3-23.

${ }^{25} \mathrm{Cfr}$. IGyA, II, n $30,28 . X .1880$, p.371.

${ }^{26}$ SOTO FREIRE, op. cit., p. 55-56.

${ }^{27}$ Cfr. Alfredo Vicenti, Prensa periódica de Galicia, en IGyA, III, n ${ }^{\circ}$ 6, 18.IX.1881, p. 310 .

${ }^{28} \mathrm{~V}$. por ejemplo noticias de la lectura pública de composiciones de F.M. de la I. en el teatro (GRUR, II, $\mathrm{n}^{\circ} 27,1^{\circ}$.XI.1861, p. 429) o «en la última velada literaria celebrada en la casa de los señores Condes de Pardo Bazán» (IGyA, III, n 17,18.VI.1881, p. 201). En 1858 , con ocasión de los festejos celebrados al inauguración en La Coruña de las obras del ferrocarril, las carrozas alegóricas que recorrieron la ciudad iban «arrojando coronas de laurel e inspiradas poesías de D. Francisco de la Iglesia ....»: cfr. Félix ESTRADA CATOIRA, Contribución a la historia de La Coruña. La Reunión recreativa e instructiva de artesanos en sus ochenta y tres años de vida y actuación, La Coruña, 1986, p. 48.

${ }^{29}$ Una parte mínima de la obra de Francisco fue publicada por Fr. Gumersindo Placer con el título Do mar e da terra. Poesías inéditas e recollidas por el P. Mercedario, Ed. Mercedaria, Madrid, 1930.

"CUADERnOS DE ESTUdios GALLEGOS", Tomo XLVII, Fascículo 113, Santiago 2000. 
los ideales de la temperie romántica en que se formaron aquellos hombres aunque el tono general y los métodos seguidos deban mucho a la supervivencia de la concepción ilustrada del saber. Por eso la erudición y la prosa científica conviven con la creación literaria, especialmente poética, y con el recién descubierto folklore. Al fondo, constantemente, el poder milagroso del pensamiento racional.

\section{COLABORADORES}

Para demostrar que Galicia no era ningún erial bastaba convocar a los talentos del país y a sus simpatizantes. Al llamamiento respondieron en legión los escritores más heterogéneos de Galicia y de la diáspora, unidos por un mismo talante: la salvación colectiva. Bajo la batuta de los dos hermanos y en pos del universalismo anunciado en el título, se dieron cita poetas y literatos, científicos, marinos y juristas, vivos o desaparecidos, decididos a mostrar al mundo las glorias de la patria. Muchos practicaban el periodismo cultural alternándolo a una profesión liberal, prueba de que a esas alturas del siglo XIX el ejercicio de las letras en la prensa militante, no siempre lucrativo, daba la seguridad de ser escuchado. Algunos procedían de instituciones modernas y prestigiosas, como la Normal Central o la Escuela Superior de Diplomática, y disponían de un bagaje cultural considerable y de una erudición de ley ${ }^{30}$; otros son figuras de la ciencia médica y de la docencia universitaria ${ }^{31}$; hay simpatizantes forasteros, como

\footnotetext{
${ }^{30}$ Tal es el caso de historiadores como Villaamil: cfr. Historiografia, en Gran Enciclopedia Gallega, S. Cañada, Gijón, 1974.

${ }^{31}$ Varela de Montes, José María Gil, Díaz de Robles y López de la Vega, eran médicos; José Pardo Bazán, Vicente Turnes y Paz Novoa, juristas; catedráticos Planellas y García Mosquera; científicos Vázquez Queipo, Saavedra Meneses, Casiano de Prado, Martínez Servida y López Seoane; arquitectos Manuel de Prado y Faustino Domínguez; junto a ellos, músicos como Varela Silvari y miembros de la Marina de distinto grado y función como Saralegui y García Boado, simple «maestre de víveres» de laArmada; bien conocidos los más, postergado alguno por razones políticas, como Casiano de Prado, geólogo más conocido en Paris y Londres que en su propia tierra: v. Gran Enciclopedia Gallega, cit., XXV, pp.205-206, que hace hincapié en el olvido a que lo condenó su patria; X.A. FRAGA VÁZQUEZ, Victor López Seoane, «Revista del Instituto J. Cornide de Estudios Coruñeses», 1992.
}

"CUADERNOS DE ESTUDIOS GALLEGOS", Tomo XLVII, Fascículo 113, Santiago 2000. 
RuizAguilera, F. de P. Madrazo o Navarro Villoslada; y, last but not least, poetisas y narradoras bien convencidas de la importancia de su acción en la sociedad por más que sus nombres, exceptuado el de Rosalía, nada digan al público de hoy. Ésta era la ocasión para anunciar al mundo no sólo la obra individual sino la plétora de capacidades que la cenicienta de España encerraba en su seno.

La ósmosis entre generaciones lleva a reproducir originales de otras publicaciones y de otros tiempos, practicándose también a menudo el préstamo por coincidencia de intereses. Este frente de colaboradores, miembros del grupo social surgido de la revolución burguesa, se muestra pronto a dirigir la escena desde el punto de vista de unos valores culturales en alza si bien marginado coyunturalmente por carecer del prestigio que comunicaba el dinero. Enamorados de las letras, a pesar de la insignificancia del estatuto del intelectual en una sociedad sometida al primado económico, se erigen en intérpretes de la situación con conciencia de su papel rector. Y, como hombres nuevos, adscritos a las clases medias urbanas si bien cordialmente próximos al mundo semirrural que los rodeaba, se atreven a disentir de la inoperancia y ceguedad generales y a presentar batalla con ilimitada confianza en el poder de la prensa. Su lema es la «santa unión» de los periodistas ${ }^{32}$.

De la generación romántica adoptan la entrega total a una misión civilizadora en cuyo éxito confían y transmitiendo sus saberes por medio de la letra impresa trazan un nuevo «retrato de la patria» que consigne al mundo «los títulos en que funda su civilización» ${ }^{33}$. Sin pertenecer a una única escuela ni a una sola generación, su cemento de unión es la fe en la cultura. Coinciden en atribuir poderes carismáticos a la instrucción generalizada y esperan milagros de la penetración del maestro a todos los niveles sociales. Por cultura no entienden sólo lo que se aprende en las aulas sino el fermento vivo de la realidad de cada día. Así, supliendo la impotencia del Estado en materia educativa, crean un concepto alternativo de cultura que descubre en los niveles más bajos de la sociedad valores vivos e inéditos. Y se brindan a actuar como intermediarios entre el pueblo ilite-

\footnotetext{
${ }^{32}$ A. de la IGLESIA, El periodismo en Galicia, I, 1.I.1860, n 7, pp. 97-99.

${ }^{33} \mathrm{I}, 1 . \mathrm{X} .1860, \mathrm{n}^{\circ} 1$, p. 2.
}

"CUADERNOS DE ESTUDIOS GALLEGOS", Tomo XLVII, Fascículo 113, Santiago 2000. 
rato y las clases dominantes para que la integración de esos dos mundos incomunicados confluya hacia la salvación colectiva.

No es posible definir a los escritores que en este momento histórico se hacen intérpretes del renacimiento de su tierra sin recordar su origen, casi siempre ajeno a la hidalguía (o entroncado, si acaso, con su arruinada rama rural) o a la clase social de rentistas salida de la desamortización y dependiente de esa fuente de ingresos. Los doctos suelen estar desligados de las rentas capitalistas: viven de una carrera, sin más bienes de fortuna que su cultura, su sensibilidad y una penetración que los transforma en críticos implacables, con un dinamismo y una capacidad de juzgar que los sitúa automaticamente por encima de los rentistas, dueños del poder material pero adocenados ${ }^{34}$. Aunque ajenos a la política e hipercríticos hacia ella, no se desentienden de la España oficial sino que la invocan con la voz de la prensa, de la que reciben el reconocimiento y el influjo escatimados al hombre de letras por la sociedad del tanto vales cuanto tienes. No se conforman, como poco después los noventayochistas, con contemplar de lejos la crisis de identidad colectiva ${ }^{35}$ sino que, interesados al máximo en el acontecer histórico, sueñan con otra España y hacen lo que está en su mano por ayudarla a nacer. Pero, aunque luchadores incansables, más que rebeldes al sistema son espíritus inquietos que quieren protagonizar el proceso de cambio, dar contenido al descontento y preterición evidentes de su tierra y conformar el futuro desde un conocimiento exacto del pasado. Su proximidad al socialismo utópico a la francesa los convierte en portavoz de un descontento de raíz económica y moral y los lleva a hacer causa común con los más desfavorecidos. Evidente es su relación con un cristianismo más hondo y evangelicamente auténtico que el vivido hasta allí por la sociedad española, tal como lo simbolizaba Pastor Díaz. Por eso, aunque no descuiden la primacía de la caridad, atienden con otros ojos a las capas inferiores y sueñan con emanciparlas por medio de la instrucción, idea heredada del primer liberalismo. De ahí recogen también la atención al problema agrario, meollo de la revolución burguesa, y

\footnotetext{
${ }^{34}$ Confidencias sobre estrecheces económicas y logros profesionales en J. López de la Vega a A. de la I., Santiago, 5.IX.1863; Antonio Santiago Somoza a F. de la I., Madrid, 8.XII.1861: RAG, Donación de la Iglesia, caja 97.

${ }^{35}$ Cfr. Inman FOX, La invención de España, Cátedra, Madrid, 1997, p. 132.
} 
con optimismo progresista pretenden dignificar al campesino antes que las tensiones sociales se exacerben. Pero, aun lamentando la proletarización del campesinado, un sentido del decoro muy burgués los aleja de la liza política. Para comprender tal compostura quizá baste recordar que «los románticos subversivos formaban una pequeña minoría y provocaron una violenta reacción entre los bienpensantes ${ }^{36}{ }^{3}$. Su descontento resulta siempre incompatible con cualquier forma airada de disensión, como las que teñirían al poco la acción de las asociaciones proletarias y del regionalismo maduro.

\section{EL PRESENTE Y EL FUTURO}

La recepción del nuevo nacionalismo europeo está en el germen de esta revista. Doce años después del auténtico Völkerfrühling esta aventura intelectual es eco de la «primavera de los pueblos» ${ }^{37}$ que anuncia una nueva era y encauza una corriente de pensamiento todavía desligada de la acción política. Con todo, política es su voluntad de llevar a los gallegos a descubrirse a sí mismos, de arrancarlos de la pasividad moral y emanciparlos de un secular complejo de inferioridad, de impulsarlos a descubrir su dignidad para, una vez madurado el sentimiento de comunidad, enaltecerse como pueblo. Aparte de su valor cultural y de defensa de un patrimonio en trance de perecer, el sentido último de la revista es también político en cuanto aspira a profundizar los logros de la cultura con miras a mejorar las costumbres colectivas y el nivel de la sociedad. Lo que distingue la nueva conciencia de galleguidad es la cooperación al engrandecimiento peninsular, con miras a beneficiarse del progreso material, incomparable conquista del siglo. Causa y efecto a la vez del desarrollo, la educación generalizada sería el primer paso para romper el aislamiento material y cultural de Galicia con el resto de la Península. En la mente de

${ }^{36}$ Cfr. Donald SHAW, El prólogo de Pastor Díaz a las poesías de Zorrilla (1837): contexto y significado, en De místicos y mágicos, clásicos y románticos. Homenaje a Ermanno Caldera, A. Siciliano Ed., Messina, 1993, p. 473.

${ }^{37}$ Cfr. José María JOVER ZAMORA, La civilización española a mediados del siglo $X I X$, Espasa-Calpe, 1991, p.152.

"CUADERNOS DE ESTUDIOS GALLEGOS", Tomo XLVII, Fascículo 113, Santiago 2000. 
estos progresistas la cultura reemplaza el papel de la religión como medio de unificar las conciencias ${ }^{38}$. De aquí el constante elogio de la escuela, generadora de cohesión moral, extraordinariamente llamativo dado el contexto de dramática pobreza en que se hacía.

Coincidiendo con la abolición de la esclavitud y poco antes de que los narodniki rusos marchasen a emancipar a los siervos de la gleba, esta revista introduce en el debate cultural inesperadas consideraciones sobre la desastrada existencia de las masas populares de su tierra. Su denuncia pacata pero firme de la despiadada ferocidad del laissez faire pretende superar con medios legales el desnivel que aniquila a la sociedad. Porque aun sin tocar a rebato, sin aspavientos, quienes en ella colaboran, adscritos como están a las clases medias urbanas, se solidarizan con el mundo rural y no temen pregonar a los cuatro vientos el malestar económico y moral de los desheredados. Sólo que en vez de apelarse a la caridad, como el idolatrado Pastor Díaz, proclaman lo injusto del desnivel de todo género que mina la vida colectiva y sugieren superarlo con la difusión general de la cultura ${ }^{39}$. Más que remozar la fórmula ilustrada de «educación popular» lo que intentan es equiparar fraternidad evangélica y fraternidad civil, haciendo justicia a todos los miembros de la colectividad. Bajo la acción tutelar del Estado colocan los ideales de revolución burguesa que se cifraban en una aplicación racional de la igualdad. Sólo así se podría corregir la coyuntura y acabar con analfabetismo y miseria, plagas seculares de Galicia que aliadas al arcaísmo del cultivo y a una administración vejatoria para el paisano no le dejaban levantar cabeza. La dignidad de ciudadanos alcanzaría así a la muchedumbre de miserables destripaterrones, abocados al «temible feudalismo» de una industrialización inevita-

\footnotetext{
${ }^{38}$ Sobre el papel de la religión como medio educativo en R. de la Sagra, cfr. CAMBRÓN, op. cit., p. 243.

${ }^{39}$ V. la petición de escuelas dominicales de F.de la I. al Gobierno de provincia que corrige el espíritu puramente ordenancista y represivo de la circular sobre servicio doméstico a la que sirve de comentario: v. II, 15.XII.1861, nº 30, pp. 479-480; id., Formación de un plan de enseñaza agrícola por el Gobierno, III, 15.VI.1862, n ${ }^{\circ} 12$, pp. 183186. Cfr. V. CACHO VIÚ, Crisis del positivismo, derrota de 1898 y morales colectivas, en Visperas del 98, Biblioteca Nueva, Madrid, 1997, p. 230, se refiere al escepticismo de Costa con respecto a los intelectuales, poco dados a la acción, y a su búsqueda de soluciones más expeditivas para la crisis social que la clave pedagógica defendida por la Institución Libre de Enseñanza.
}

"CUADERNOS DE ESTUDIOS GALLEGOS", Tomo XLVII, Fascículo 113, Santiago 2000. 
ble ${ }^{40}$. Entre incitaciones al Gobierno y críticas a su actuación se va perfilando la batalla a favor de las escuelas de primeras letras que con un plan de educación rápida y conocimientos técnicos daría definitivamente al maestro rural el papel que antaño desempeñaba el cura y todavía añoraban algunos.

La defensa que hace GRUR de la agricultura y del campesino pobre refleja los afanes de la Sociedad Económica de Santiago y pide protección para él antes que la proletarización lo aniquilase ${ }^{41}$. Sin bancos agrícolas, sin espíritu de asociación, sin conocimientos técnicos, la ruina rural se comprobaba con el aumento de la emigración a América de los últimos quince años ${ }^{42}$. Esa preocupación obsesiva por las condiciones desastrosas del campo dicta infinidad de artículos y tiene como colofón los debates del Congreso agrícola de Santiago ${ }^{43}$ pero no acepta resignada la agricultura como único recurso. Al revés: como sería quimérico pensar en una recuperación material sin ayuda de la moderna tecnología se ensalza cualquiera de sus rasgos, incluso mínimos. De ahí el elogio del tecnefón o «aparato de hablar», invención de un pontevedrés ${ }^{44}$. Bajo el signo del ca-

${ }^{40} \mathrm{~F}$. de la IGLESIA, p. 186 cit.

${ }^{41}$ José VARELA DE MONTES, Discurso ..., IV, 15.X.1863, nº 20, p. 239; José PARDO BAZÁN-Conde de PALLARES, Memoria sobre la necesidad de establecer escuelas de agricultura en Galicia, II, $\mathrm{n}^{\circ} 16,15$. VIII.1862, p. 254, afirma el deber del Estado en el terreno de la instrucción y critica la insuficiencia del presupuesto estatal; Cfr. F. M. de la IGLESIA, Formación de un plan de enseñanza agrícola por el Gobierno, III, 15.VI.1862, $\mathrm{n}^{\circ} 12$, p. 186. A. de la IGLESIA. añade su granito de arena al debate sobre creación de escuelas rurales promovido por el Rector de la Universidad de Santiago y en que interviene el arquitecto de la Diputación Faustino Domínguez: v. Construcción de edificios para la enseñanza pública, III, 15.IX.1862, n 18, pp. 285-286; cfr. J. A. SÁNCHEZ GARCÍA, F. Domínguez y la arquitectura gallega del siglo XIX, Diputación Provincial, La Coruña, 1997, pp. 111 y 149. En este ambiente fervoroso se gesta la creación de la Granja Escuela de La Coruña, financiada con la ingente fortuna de la Condesa de Espoz y Mina.

${ }^{42}$ PARDO BAZÁN-PALLARES, op. cit., p. 223; v. el reflejo del problema a nivel poético en dos famosísimas composiciones: Adios qu'eu voume, de Rosalía, III, 15.VIII.1862, n 16 , pp. 252-252; y Muiñeira da despedida, de A. de la I., II, $1^{\circ}$.VI.1861, $\mathrm{n}^{\circ} 17, \mathrm{p} .270$.

${ }^{43} \mathrm{~V}$. su transcripción en IV, pp. 205 y passim.

${ }^{44}$ El Tecnefon, V, $1^{\circ}$.II.1864, n 3, pp. 37-37; cfr. Severino PÉREZ Y VÁZQUEZ, El Tecnefón y los medios representativos de la palabra, Imprenta del Colegio de Sordomudos y de Ciegos, calle de San Mateo n. 5, Madrid, 1868, $4^{\circ}$ mayor, 40 págs.

"CUADERNOS DE ESTUDIOS GALLEGOS", Tomo XLVII, Fascículo 113, Santiago 2000. 
pitalismo surgían promesas de avance alternativas, algunas en plena realización como el ensanche y derribo de las antiguas murallas, otras de solera acreditada como el arsenal ferrolano, principal concentración fabril gallega ${ }^{45}$.

Esa línea de pensamiento explica el enorme espacio que la revista dedica al ferrocarril. Muchas páginas tratan de los beneficios que traería al aproximar la Corte lejana y dar salida a los recursos locales o introducidos en Galicia por el comercio marítimo extranjero. Tanta fe ante el progreso -desmedida a nuestros ojos- no es deslumbramiento provinciano sino ambición bien fundada e indispensable para resucitar una economía mortecina ${ }^{46}$. El ferrocarril promete estimular la cohesión peninsular frente a vetustas y ridículas pasiones localistas de propietarios temerosos del impacto económico y social de la modernización del transporte ${ }^{47}$. De ahí la constante defensa de la apertura hacia lo exterior, reconocimiento implícito de que sólo al contacto entre culturas se debía el florecimiento de la Galicia medieval. Y como la acuciante crisis económica europea de 1855 a 1866 había hecho retraerse al capital extranjero de inversiones hasta allí productivas, GRUR emprende una campaña publicitaria para que el país entero prohijase la empresa ferroviaria formando un frente de accionistas que garantizase la conclusión de la línea ${ }^{48}$.

${ }^{45}$ A. de la I., Mejoras de La Coruña, IV, $1^{\circ}$.IV.1863, nº 7, pp. 49-51; cfr. Jesús Ángel SÁNCHEZ GARCÍA, La construcción de la ciudad burguesa en Galicia. La Coruña 1840-1870, en «Abrente», 27-28, 1995-1996, pp. 181-212; sobre la reestructuración de Vigo en vista de sus relaciones con Oporto cfr. «El Porvenir Hispano-Lusitano. Revista de comercio, industria, ferro-carriles, telégrafos y letras», 1858, passim; sobre la unión ferroviaria Ferrol-Vigo, I, 15.XI.1860, n 4, p. 61.

${ }^{46} \mathrm{~V}$. el papel primordial que atribuye a ese fervor Alexander GERSCHENKRON, El atraso económico en su perspectiva histórica, Ariel, Barcelona, 1968, p. 33.

${ }^{47}$ Cfr. V, $1^{\circ} . X .1864, n^{\circ} 19$, pp. 290-301.

${ }^{48}$ A. de la IGLESIA, Ferrocarriles de Galicia, III, 15.VII.1863, no 14, pp. 137-139. Sobre el fraude sistemático de tales negocios recuerda Gabriel TORTELLÁ CASARES en Los orígenes del capitalismo en España, Tecnos, Madrid, 1973, p. 168 y 169, que «las Cortes se convirtieron a partir de 1851 en un campo de caza de concesiones provisionales que se obtenían por influencia y sobornando a diputados y senadores, y que más tarde se vendían a precios crecientes, pasando de mano en mano sin que ninguno de los sucesivos adquirentes hiciera ningún esfuerzo por empezar la construcción de la línea concedida [...] en casos los contratistas se embolsaron la subvención sin dedicar un sólo céntimo a los gastos de la obra». Otros detalles en SAURIN DE LA IGLESIA, Apuntes ...,

"CUADERNOS DE ESTUdiOS GALLEGOS", Tomo XLVII, Fascículo 113, Santiago 2000. 
La entusiástica campaña a favor del ferrocarril patentiza cómo el humanitarismo de estos escritores ve un servicio cívico en la labor intelectual. Con los medios a su alcance-simples opiniones, informes o reelaboraciones literarias- se esfuerzan por interpretar el estado de ánimo general y mueven los ánimos contra la proverbial miseria gallega que el ferrocarril vendría a remediar: menester previsto por la poética romántica que, dando por descontada la existencia de un alma colectiva, adjudicaba al poeta la posibilidad de interpretarla en el peculiar acto comunicativo que es la poesía ${ }^{49}$. Tal actitud implica un concepto totalizador de la sociedad que reconoce en el pueblo el depositario de la personalidad colectiva y adjudica a los intelectuales su defensa y salvación. Ellos se brindan a salvar el abismo que separa a cultos e iletrados, a captar los matices recónditos del mundo de los pobres, subalterno y despreciado pero indispensable para fijar los perfiles desdibujados de una personalidad histórica común. Al pretender respeto y atención a los más desfavorecidos delinean el ser de Galicia como entidad amenazada de extinción, de cuya supervivencia se sienten responsables. Y, como todavía hay fe en la España oficial, se erigen en sus defensores ante las más altas instancias.

Algún arranque de anticolonialismo foráneo insinúa la conveniencia de la explotación de Galicia por gallegos aunque predomina la incitación a los representantes parlamentarios para lograr una mínima protección gubernativa y hacer de Galicia otra Cataluña. La mesura, el deliberado apoliticismo de la revista y su rechazo a formular teorías no ocultan profunda insatisfacción ante un sistema apoyado en la pasividad de los electores y en un caciquismo de antiguo arraigo ${ }^{50}$. Pero ni recordarle al Estado

cit., pp. 209 y sigs. No faltan ejemplos de cómo ciertas convergencias políticas o económicas alimentaban una propaganda interesada. Los ingentes beneficios en juego hicieron surgir de la nada órganos de prensa cuyas conexiones con las empresas ferroviarias no han sido estudiadas. Los ambientes literarios progresistas se dejaban atraer facilmente por la gran ocasión de rescate representada por el ferrocarril: v. en Pontevedra, 1853, «El Ferrocarril»; en La Coruña, 1858, «El Ferrocarril del Príncipe D.Alfonso»; en Vigo, 1859, «El Porvenir Hispano-Lusitano».

${ }^{49}$ Leonardo ROMERO TOVAR, Panorama crítico del romanticismo español, Castalia, Madrid, 1994, p. 227.

${ }^{50} \mathrm{~V}$. opiniones tajantes sobre el falseamiento del sentido del Estado entrañado en la existencia de los caciques, sobre el derecho a votar y la burla electoral, sobre trapicheos políticos en las contratas de ferrocarriles: A. de la IGLESIA., IV, 15.VII.1863, n 14, pp.

"CUADERNOS DE ESTUDIOS GALLEGOS", Tomo XLVII, Fascículo 113, Santiago 2000. 
sus deberes equivale en estas fechas a poner en tela de juicio la representatividad parlamentaria de los diputados gallegos, ni animar a éstos a hacerse oír supone subversión alguna ${ }^{51}$. Por eso no se ahorran críticas a promesas de recuperación que no acababan de despegar, como el ferrocarril aplazado sine die, la dependencia de suministros extranjeros, la insuficiencia de los muelles o de los caminos vecinales, arterias indispensables para vivificar la vida local. Los intelectuales, gente de bien, no se enardecen ni se solidarizan con la agitación política pero al disentir de la administración pública por su ineficacia demuestran innegable valentía aunque lo hagan guardando las formas. Su mesura y ponderación en el vital asunto de la revolución de los transportes no resta firmeza a la exigencia de que el Estado se responsabilice de la conclusión de la línea ferroviaria. Sólo rompiendo su aislamiento quedarían conjurados los males de que adolecía Galicia. Cuando esa esperanza quede defraudada una vez más y con ella la supervivencia material de un pueblo entero, será ya imposible discutir el tema con la frialdad de una cuestión académica. Pero para entonces la revista habrá dejado de existir.

\section{LA LECCIÓN DEL PASADO}

La argumentación impecable que exigía recobrar la dignidad perdida $\mathrm{y}$ con ella un papel de primer orden en el concierto nacional da calidad patriótica a cualquier esfuerzo de reconstrucción, ya fuera en lo material o en lo cultural y artístico. ¿Podría un pueblo salir de su inercia y recobrar el sentimiento de identidad sin noción de lo que había sido? Para hacer frente al culpable desconocimiento de lo propio, la revista conjuga la exploración del pasado a través de los estudios históricos -fórmula heredada de la escuela romántica- con el análisis de las circunstancias presentes. Y hace confluir todo ello en un concepto más amplio de nación española que no pone en tela de juicio la fidelidad a la patria común ni alude por

137-139. El populismo de A. de la IGLESIA se enfrenta con la versión oficial que justificaba un episodio de represión violenta en el cobro de contribuciones: Honor de Galicia vindicado, VI, $1^{\circ}$.VI.1865, n 11, pp. 161-162; cfr. M. R. S. de la I., Apuntes.., cit., pp. $274-275$ y $327-329$.

${ }^{51}$ A. S. SOMOZA, A los Diputados por Galicia, I, 15.XI.1860, n 4, pp.60-61.

"CUADERNOS DE ESTUDIOS GALLEGOS", Tomo XLVII, Fascículo 113, Santiago 2000. 
consiguiente a la necesidad de aflojar lazos con España sino que trata de conjugar dentro del Estado unitario una voz sin resonancia hasta allí. Nada en esta postura entraña rebeldía ni apunta a descubrir una misión histórica propia como algo desligado del resto de España. Al contrario, la continuidad nacional improntada por Castilla aparece intensamente sentida y celebrada, ante todo en clave poética. La epifanía de Galicia, revelación alborozada de su ser auténtico, desvanecido durante siglos, se enfrenta al desconocimiento y desprecio que la circundan, ahonda en el acervo histórico-literario del pasado y reconstruye la tradición interrumpida. La historia así vivificada contribuye a fundamentar el sentimiento patriótico, abandona la estéril erudición y se apresta a la acción cívica, rehabilita el pasado con instrumentos modernos de análisis e interpretación y muestra cómo, tras la rudeza presente, latía una cultura truncada en su desarrollo. Al desconocimiento de una historia jamás escrita sucedía ahora la revelación de lo oculto; una lengua, venerable pero desprovista de gramática y diccionario, empezaba a brillar expresando algo más que mezquindades de palurdos. Todo esto no se explica sin la adhesión a corrientes de pensamiento que del concepto romántico de nación habían hecho una clave de la modernidad. Surgen de ahí una historiografía y una literatura que excitan la autoestima pero sin ansias polémicas ni ideas preconcebidas. Esa ambición de imparcialidad fija la crítica científica como norma para adoctrinar racionalmente a los gallegos y se refleja en el amplio margen concedido a la publicación de documentos de archivo, único modo de deslindar lo legendario de lo demostrable.

La relación entre la historia y otras ramas del saber valoriza el arte, cuyo estudio se encuentra en sus albores, y contribuye a forjar una interpretación estética de Galicia. Las descripciones de monumentos hechas con rigor analítico ejemplar denotan una fruición ante la belleza antigua teñida de dolor por la ruina a que están abocados. Ante la carencia de instituciones que preserven ese patrimonio riquísimo se pide con afán la organización de archivos, la publicación de fuentes. Todo ello peligra por inoperancia del Estado, imitado en su ceguedad y atraso por las administraciones locales. A falta de sentido del deber en las instancias superiores la minoría intelectual enseña el respeto a las reliquias del pasado: así, mientras los más admirables monumentos se derrumban entre la indiferencia general y la transferencia de los bienes monacales hace desaparecer preciosos documentos, podridos o vendidos al peso, la invocación al 
espíritu de asociación local insta a salvar ese mundo de recuerdos. La denuncia sistemática de las barbaridades cometidas tras la Desamortización no se limita a evocar una nostálgica imagen de castillos medievales y conventos ruinosos sino que acaba por anticipar a escala local la polémica sobre la ciencia española ${ }^{52}$.

Poco a poco se afianza así un movimiento de opinión sobre la labor de acarreo histórico. Los hermanos de la Iglesia, sin falsa modestia, tienen clara conciencia de las limitaciones tanto personales como del ambiente para edificar una historia de Galicia a la altura de su objeto y, por conocer la insuficiencia del punto de partida y el atraso de los estudios científicos, cifran el programa de la revista en la elaboración de monografias más que de grandes panoramas de conjunto. No para aplazar indefinidamente la tarea, ni como pretexto para rebajar el tono de la investigación historiográfica con desahogos de aficionados, sino por seriedad científica. Pero la limitación de objetivos y su aparente modestia tienen doble alcance; mientras sientan las bases de una auténtica ciencia histórica local antes de formular reconstrucciones totales, corroboran con el conocimiento de la importancia pasada un orgullo nacional de buena ley. Sólo de la propia estimación nacería el comportamiento a seguir en el futuro. Por otra parte, bastante novedosa es en sí la reconstrucción del pasado no a base de imaginación, según había hecho hasta allí la fantasía romántica, sino partiendo de material documental serio ${ }^{53}$.

\footnotetext{
52 «... en Galicia no hay una sola ciudad que tenga el más pequeño museo artístico ni arqueológico, y el que tales cosas habla pasa por un visionario o monomaníaco»: $E l$ castillo de la Rocha, cit., p. 107; «No sé cómo tenemos valor para hablar de bellas artes en el siglo XIX», afirma A. de la IGLESIA condenando la ruina de edificios notables: Recuerdos de Santiago, II, $\mathrm{n}^{\circ} 22,15$. VIII.1861, p. 338. Sugiere soluciones prácticas: destinar a la enseñanza pública o a hospital edificios monásticos como Santa Catalina de Montefaro, Conxo y Sobrado antes que verlos derrumbarse. Igual protección pide para consolidar valores modernos, bibliotecas públicas, museos : $\mathrm{V}, \mathrm{n}^{\circ} 21,1^{\circ}$.XI.1864, pp. 329-31; sobre el gabinete del naturalista López Seoane, III, $\mathrm{n}^{\circ} 21,1^{\circ}$.XI.1862, p. 323. Acerca del vandalismo crecido al amparo del Estado, derribos de obras de arte para obras públicas a poco precio, etc: M. R. SAURIN DE LA IGLESIA, Apuntes ..., cit., pp. 204205 y $223-224$.

53 «Recoger materiales para la historia de Galicia es uno de los puntos principales a que se consagra nuestra publicación. Si llegásemos a acopiar tantos apuntes históricos como sean suficientes para en su vista escribir la historia general del país, no faltará después escritor que a tan serio como importante trabajo se dedique, donde no escasea [...] el genio, el estudio, la crítica para dar a luz una obra tan necesaria si Galicia ha de
}

"CUADERNOS DE ESTUDIOS GALLEGOS", Tomo XLVII, Fascículo 113, Santiago 2000. 
Nace así una serie de ensayos de tenor muy distinto a los de la prensa anterior pues su punto de partida es el examen crítico de documentos de diferentes procedencias, transcritos casi siempre. Esta labor preparatoria lleva a publicar textos antiguos salvados del expolio de los archivos monacales, o inéditos elaborados por eruditos como el que fuera bibliotecario de la Universidad de Santiago Francisco Javier Rodríguez, recopilador incansable de datos sobre los arzobispos de Santiago, de sus dominios y fortalezas. Se reproducen papeles pertenecientes a la Academia de la Historia y a la Biblioteca Nacional ${ }^{54}$ y se transcriben instrumentos que el director o los colaboradores poseían en copia ${ }^{55}$; por primera vez se saca partido de la epigrafía y la numismática, se hace un preciso balance bibliográfico sobre temas locales y se describen monumentos en trance de desaparición. No faltan tampoco declaraciones que ilustren la actitud del editor hacia las fuentes que publicaba ${ }^{56}$.

El predominio de esos criterios científicos impide que el pasado se transforme en mito consolatorio. Y aunque no siempre sea evidente el aspecto pragmático de estos estudios, se deduce de la historia local una hermosa lección, encaminada a educar al pueblo gallego y a rescatarlo de

conquistar el nombre a que le dan derecho sus hazañas, si ha de elevarse con la sabiduría de lo que fue, si ha de adquirir conciencia de lo que puede ser y si ha de transmitir a sus sucesores ese impulso natural de un amante padre a sus hijos guiándolos por el camino del honor, del bien y de la fama»: I, $n^{\circ} 8$, 15.I.1861, p. 112. Y más tarde: «Siendo nuestro objeto principal consignar en las columnas de la 'Galicia' cuantos datos podamos acopiar relativos a la historia de este antiguo Reino, al carácter físico y moral de sus naturales, a su antigua y moderna literatura, costumbres y progresos, como basa del gran trabajo histórico que en no lejanos días debe fotografiar nuestra querida patria ...»; $\mathrm{V}, 1^{\circ}$.II.1864, $\mathrm{n}^{\circ} 3$, p. 35.

${ }^{54} \mathrm{IV}, 15 . \mathrm{IX} .1863, \mathrm{n}^{\circ} 18$, p. 211 y sigs.

${ }^{55}$ III, $\mathrm{n}^{\circ}$ 18, 15.IX.1862, pp. 276-278 y sigs.; cfr. RAG, Donación de la Iglesia, Caja 106: copias antiguas de documentos de la Encomienda de Portomarín, noticia de privilegios reales, escrituras de Parga, Nogueira, Viana, Furelos, extracto del tumbo de Santo Domingo de Pontevedra, etc.

${ }^{56}$ Pensando en un público abigarrado, A. de la I. transcribe unas páginas sobre la cuestión del tormento indicando: «son cuadros para el poeta, son apuntes para el historiador, son pruebas para los profanos de que el someter a los hombres a cuestión de tormento no fue exclusivo de un solo tribunal. Son datos acerca de la dureza general de las costumbres y las leyes en siglos anteriores ... Así al historiador como al novelista, al periodista como al literato, al publicista como al lector conviene tener idea de la verdad de las cosas ...»: II, $\mathrm{n}^{\circ} 9,1^{\circ} . \mathrm{II} .1861$, p. 138.

"CUADERNOS DE ESTUdIOS GALlEGOS", Tomo XLVII, Fascículo 113, Santiago 2000. 
la menor edad actual. No interesa, en cambio, subrayar cada descubrimiento del pasado como prueba irrebatible de la singularidad local o como hecho diferencial justificativo de tratamiento de excepción. Tampoco se observa una excesiva gravitación hacia el pasado, que los estudios arqueológicos e históricos ponen de manifiesto sin instrumentalizarlo. Por eso el celtismo es sólo un ingrediente más entre los muchos de un ayer ignoto que atrae por igual a estudiosos y poetas, sin visos aún de mitología reivindicativa ${ }^{57}$. Tan aséptico acercamiento al pasado es diametralmente opuesto al que en breve rodeará a la exaltación regionalista y, acaso por eso mismo, cuando la afectividad haya invadido definitivamente lo científico, merecerá las críticas de los nuevos militantes ${ }^{58}$. Será la coyuntura catastrófica del finis Hispaniae lo que determine la aparición de una mitología allí donde hasta entonces había imperado la razón histórica. Y es que el regionalismo maduro representa la derrota del pensamiento racional encarnado en GRUR, cuyos colaboradores, hijos de otro tiempo y otro temple, recogían la herencia de una educación ilustrada que entendía el acercamiento a la historia sin idealizarla $a$ priori. Cierto es que en uno y otro caso el recurso a la historia tiene mucho de pragmático y ese primado de la razón práctica no olvida nunca su fin, que es conseguir un nuevo orden social y político. La historia en GRUR, si bien necesaria para ese fin, no es nunca un fin en sí misma. Quienes la escriben pertenecen a un sector de patriotas fervientes que anhelaban conocer el pasado para respetarlo y conservarlo como señal de la peculiaridad local. El ideal universal de cultura que profesan los lleva a exaltar la humanidad una y varia, la diversidad en la totalidad, la superación del particularismo capaz de armonizar en una rica polifonía la multiplicidad de voces. Por otra parte, el arraigo en el Romanticismo de casi todos los lleva a sentirse más a gusto en el mundo del arte y de la literatura que en el de la acción. Tras el 98, por el contrario, el salto de cualidad es ya innegable.

${ }^{57}$ Cfr. R. BARROS SIBELO, Costumbres de las primitivas poblaciones de Galicia..., I, $1^{\circ}$. XI.1860, nº 3 , pp. 33-35.

${ }^{58} \ll$... los hermanos Antonio y Francisco de la Iglesia, tan conocidos por sus variados trabajos, que mejor dirigidos hubieran sido más provechosos para Galicia»: Eugenio CARRÉ ALDAO, La literatura gallega en el siglo XIX, Librería Regional de Carré, La Coruña, 1903, pp. 31-32.

"CUADERNOS DE ESTUDIOS GALLEGOS", Tomo XLVII, Fascículo 113, Santiago 2000. 


\section{EL DESCUBRIMIENTO DEL FOLKLORE}

GRUR no usa aún este neologismo pero está embebida de su espíritu. Al lado de la recuperación de textos escritos reveladores del pasado ignoto, observa el comportamiento de los estratos inferiores de la población y registra sus varios matices. La creencia en el alma de la nación, más viva en el medio rural que en los ambientes cultos y maleados por un intelectualismo cosmopolita, lleva a revalorizar ese mundo subalterno, puro e incontaminado, ignorado de las estructuras estatales si no maltrado por ellas. Captar esa voz ingenua a través de sus formas de expresión más auténticas había sido en toda Europa tarea de filósofos e historiadores y da lugar ahora a una urgente meditación sobre las particularidades de la cultura local, sofocada por la apisonadora de la centralización. Es el concepto de la nación como organismo viviente y dotado de alma propia lo que impulsa a buscar en el hontanar profundo y oscuro de los siglos la secreta amalgama, casi biológica, de la colectividad, tal como se reflejaba en lengua, costumbres, cantos y consejas, y a exaltar lo autóctono como aportación a un resurgimiento general. El amor hacia lo característico de la tierra, aun en sus aspectos más insignificantes, descubre tradiciones que inflaman la imaginación inspirando una nueva literatura. Esos matices entrañables de la existencia colectiva favorecen un concepto de historia muy próximo a lo que el idealismo consideraba historia interna, incomparablemente más rico que el habitual, ya que no cede al predominio de vicisitudes militares o políticas ni se limita a escarceos estéticos.

Reconocer el valor de esa cultura inferior, fragmentada y localista, lleva a captar estratos recónditos desdeñados por los historiadores de profesión y fija perfiles hasta allí imprecisos de una personalidad histórica. El interés hacia ese mundo separado propone así fuentes bien distintas de las eruditas con que se confeccionaba la historia al uso. Esa atención hacia costumbres de vida primitiva se canaliza de un lado hacia la descripción de sus modos de vida y de otro hacia la reelaboración literaria de motivos populares. Ambos aspectos están presentes con abundancia en la revista, que es una mina de material recogido entre el pueblo y forma el germen que florecerá con la Sociedad del Folklore gallego en 1883. Esa tendencia colorea textos planteados con intención originariamente arqueológica y donde acaban por recibir igual relieve el monumento arquitectónico y la

"CUADERNOS DE ESTUDIOS GALLEGOS", Tomo XLVII, Fascículo 113, Santiago 2000. 
fiesta celebrada a su alrededor ${ }^{59}$. Con frecuencia las reseñas de manifestaciones colectivas recogen el sabor exótico que les da el sello de los siglos aunque en otros casos la descripción atañe a fenómenos en plena vigencia, pero en cualquier caso esos materiales son calas en el alma del país y como tales concurren a formar la historia del pueblo gallego ${ }^{60}$. Por otra parte, reconocer que existe en los estratos inferiores una cultura digna de ser apreciada en sus diferencias entraña en cierto modo la superación de los condicionamientos de clase. De aquí no hay más que un paso a un concepto totalizador y más solidario de sociedad gallega que contrarrestase el desnivel entre campo y ciudad, entre miseria labriega y bienestar burgués. En todo caso, la difusión cultural se entiende como clave de acceso de la comunidad rural a un nivel superior y moderno.

La reelaboración del material popular lleva a veces la matriz zorrilles$\mathrm{ca}^{61}$, otras se estructura en relatos medievalizantes ${ }^{62} \mathrm{o}$ se limita a archivar con sugestivas variaciones tradiciones y consejas de innegable cuño oral ${ }^{63}$. La glosa de motivos populares y la imitación de pautas tradicionales es practicada con éxito no sólo por Rosalía Castro sino por otros poetas deslumbrados por la afectividad auténtica e incontaminada del pueblo ${ }^{64}$. Lo que rige el interés hacia el folklore no son razones comarcales sino la ambición de completar la relación entre varios niveles del ser de España, con la revelación de su existencia al mundo de los cultos. Por eso, al revés de lo que sucederá pocos años después, indagar en lo galaico no es contraponer la existencia de una nación gallega a otra española ni imponerse

${ }^{59}$ A. de la IGLESIA, La romería de San Campio, IV, $1^{\circ}$.VIII.1863, nº 15, pp. 163-167 y passim.

${ }^{60}$ B. VICETTO, Procesión de Nuestra Señora de las Angustias en Ferrol, VI, 15. VII. 1865, $\mathrm{n}^{\circ} 14$, p. 222; Carnaval de La Coruña en 1863, IV, $1^{\circ} . \mathrm{III} .1863, \mathrm{n}^{\circ} 5$, pp. 33-39.

${ }^{61} \mathrm{~B}$. de la IGLESIA, Dos flores y un amor o el voto de Chanteiro. Leyenda del siglo $X V$, IV, $1^{\circ}$.VII.1863, $\mathrm{n}^{\circ} 13$, pp. 127-131 y sigs.

${ }^{62}$ A. DE SAN MARTÍN, El castillo del hambre, I, 15.XI.1860, n 4, pp. 62-63 y passim.

${ }^{63}$ José María GIL, Una mirada hacia atrás, II, $1^{\circ}$.VI.1861, nº 17, pp. 263-267; Domingo EROSA Y FONTÁN, El monte de San Gregorio, IV, 15.XII.1863, nº 24, pp. $303-$ 305 y passim.

${ }^{64}$ Cfr. Juan Manuel PINTOS, $O$ gaiteiro, IV, 15.II.1863, no 4, pp. 26-27; F. de la IGLESIA, $O$ horfiño da arquiña, III, $\mathrm{n}^{\circ} 21,1^{\circ}$.XI.1862, pp. 331-332; A. de la IGLESIA, Muiñeira da despedida, II, $\mathrm{n}^{\circ} 17,1^{\circ}$.VI.1861, p. 270; id., O mayo, II, $\mathrm{n}^{\circ} 14,15 . I V .1861$, pp. 211-216.

"CUADERNOS DE ESTUDIOS GALLEGOS", Tomo XLVII, Fascículo 113, Santiago 2000. 
sobre las demás peculiaridades: cada una de ellas aparece tan digna de respeto como la propia, y estimables las diferencias innumerables y sutiles que caracterizan la vida de los individuos o de las naciones. En esta óptica no hay lugar para polemizar contra humillaciones presentes sino más bien para avizorar el protagonismo inédito de una pluralidad nacional hecha de mil peculiaridades. La labor de las élites alumbra así las señas de identidad de la nación gallega afianzándolas sobre un pasado y unos lazos lingüísticos peculiares.

\section{EL PAPEL DE LA HISTORIA}

El conocimiento de la historia acerca al pasado y ayuda a prever un futuro de envergadura europea. GRUR entiende el problema de España como un desnivel cultural que concede diferente peso específico a unas y otras regiones y pretende igualar a Galicia con las que más cuentan. Considerando la construcción de una historia de Galicia en su fase previa se limita a hacer circular datos inéditos o poco conocidos para «adquirir conciencia de lo que puede» ser el país [...] y «transmitir a los sucesores ese impulso». No interesa el hecho diferencial a toda costa, como querían Saralegui, Murguía y Vicetto ${ }^{65}$, sino la emulación con otros reinos de España de historia bien conocida y estudiada. En este estadio la meta no es construir una historia general de Galicia sino sentar sus bases con monografías o capítulos de un todo que había de ser su consecuencia. Ese mismo sentido tiene el acopio de escritos inéditos que desde varios enfoques brindan materiales para la historia: los textos dieciochescos de Sarmiento y del jesuita Sotelo al lado de los del catedrático de la Escuela Superior de Diplomática Tomás Muñoz y Romero ${ }^{66}$ y de las investigaciones de Rodrí-

\footnotetext{
${ }^{65}$ Cfr. Ramón VILLARES PAZ, López Ferreiro y la historiografia gallega, en «Grial», $\mathrm{n}^{\circ} 66$, oct.-dic. 1979 , pp. 429-432. Villares no considera el estadio intermedio entre la historia literaturizada a lo Vicetto y la exaltación reivindicativa del hecho diferencial a lo Murguía, y sin embargo está bien representado en GRUR. También lo pasa por alto el excelente estudio de Ramón MÁIZ, O rexionalismo galego: organización e ideoloxía (1886-1907), Ed. do Castro, La Coruña, 1984.

${ }^{66}$ Especialmente. la parte relativa a Galicia de su Diccionario bibliográfico-histórico: II, $\mathrm{n}^{\circ} 11,1^{\circ}$.III.1861, pp.164-167 y sigs., revisada y puesta al día por A. de la Iglesia.
}

"CUADERNOS DE ESTUDIOS GALLEGOS", Tomo XLVII, Fascículo 113, Santiago 2000. 
guez sobre los arzobispos de Santiago, ofrecidas en su desnuda sencillez a la degustación directa. Todo ello muy distante de la libre imaginación con que hasta allí se había escrito acerca de temas históricos. Sin desdeñar los fines estéticos, presentes al estilo romántico en consejas y tradiciones locales, prevalece la limpia indagación, la documentación rigurosa, el análisis crítico y la objetividad más escrupulosa. El gusto por la transcripción de fuentes de primera mano las brinda numerosas a la consulta crítica, y, sin caer en superficialidades como las que solían darse al público, se suceden los temas más dispares.

Un papel importante está reservado a la biografía. Más que los ecos de Carlyle -con su consideración de los grandes hombres como motor de la historia, sin cuyo impulso ascendente la sucesión de acontecimientos humanos se estancaría- resuena aquí la lección de Cantú, que también reservaba un papel privilegiado a la biografía en la historia universal. Pero la vocación didáctica del piamontés vivificaba la historia no sólo con el recuerdo de los héroes, individualidades señeras que difundieron lo noble y generoso, sino también con la aportación del personaje colectivo, limitado a hacer de coro y sin embargo imprescindible ${ }^{67}$. El lugar ocupado en la historia por alguno de esos seres representativos de una edad, una condición humana o una fase social viene dado por figuras desconocidas, ya que a menudo quienes más influyen en los destinos de la humanidad permanecen en la oscuridad ${ }^{68}$. Sin duda ese criterio es el que da voz al «maestre de víveres» de la fragata Resolución, que recoge en sus crónicas de la Escuadra del Pacífico las peripecias de aquel crucero patriótico, empresa extraordinaria y, si se quiere, heroica, aproximando las vivencias de un hombre oscuro a la curiosidad del lector ${ }^{69}$.

\footnotetext{
${ }^{67}$ «E perché la storia fu sinora dettata dalle classi privilegiate e per le privilegiate, deve necessariamente assumer aspetto diverso e mutar le sue sentenze quando pretenda farsi popolare, dettata coi sentimenti del popolo, nella fiducia di arrivare al cuor del popolo», por eso las vidas escogidas como ejemplares «non saranno sempre quelle che la letteratura ufficiale intitola eroi». Cfr. sus Biografie per corredo alla storia universale, G. Pomba e C. Ed., Torino, 1847, $3^{\text {a }}$ ed., I, p. 7.

${ }^{68}$ «... sovente tormentati e vilipesi, di nessuna espressione agli occhi volgari, mentre la vita vera, l'interna, tutta di riflessione, di sentimento, d'entusiasmo, legasi a quella del paese, del secolo, sovente del mondo»: Ibid., p. 9.

69 José GARCÍA BOEDO, Noticias de la Escuadra española del Pacífico, IV, $1^{\circ}$.VIII. $1863, \mathrm{n}^{\circ} 15$, pp. 166-168 y passim.
}

"CUADERNOS DE ESTUDIOS GALLEGOS", Tomo XLVII, Fascículo 113, Santiago 2000. 
La presentación de algunas individualidades señeras, traídas a primer plano como signo y compendio del pueblo que las produjo, denota una buena técnica historiográfica. Ejemplar es, por ejemplo, la monografía sobre María Pita, fundada en investigaciones de archivo completadas con el examen y discusión del estado de la cuestión ${ }^{70}$. Parecido esfuerzo interpretativo lleva a desempolvar figuras heterogéneas del pasado reciente, como el escultor Felipe de Castro y el historiador Cavanilles; o modernas y en pleno apogeo como el diputado Saavedra Meneses. Aportaciones de varios autores iluminan el controvertido papel de Pardo de Cela, símbolo de la oposición feudal al unitarismo de los Reyes Católicos, estudiado con imparcialidad de buena ley por Manuel Murguía, Félix Alvarez Villamil y José Villamil y Castro, colaborador éste en la Historia de Lafuente ${ }^{71}$. Equilibrado es también el elogio de las instituciones municipales, esencia del nacionalismo hispano ${ }^{72}$. Y sin duda no tiene nada de casual el mensaje de temperancia transmitido por articulistas de extracción muy distinta, ninguno de los cuales persigue la apología ni exalta valores falsos a falta de otros genuinos. Acordes en consagrar igual recuerdo a luces y sombras del medioevo, tal criterio permite abordar episodios poco honrosos sin manipularlos ${ }^{73}$. El análisis temático de hazañas y glorias de la patria, remotas o actuales, arroja una sorprendente variedad de asuntos, ofrecidos al público con extraordinario rigor documental. Con ello la historia deja de ser menester puramente literario aunque no siempre consiga desprenderse del retoricismo de expresión característico de la época, au-

${ }^{70}$ En RAG, Donación de la Iglesia, Caja 105, están reunidos varios manuscritos e impresos sobre el tema, anteriores y posteriores a GRUR.

${ }^{71}$ Particularmente significativa es la actitud del joven Murguía, antitética de la que será de rigor en el regionalismo posterior. Las primicias de su pluma aquí publicadas anticipan tesis reelaboradas luego con función diferente: Galicia víctima del feudalismo más grosero, los Reyes Católicos como salvaguardia del derecho y el orden; Pardo de Cela no como mártir de la independencia gallega sino como tirano saqueador: v. De las guerras de Galicia en el siglo XV y de su verdadero carácter, II, $\mathrm{n}^{\circ} 8,9$ y $10,15 . \mathrm{I}, 1^{\circ} \mathrm{y}$ 15.II.1861. Cfr. Justo GONZÁLEZ BERAMENDI que sintetiza la evolución de ese pensamiento en Manuel Murguía, Xunta de Galicia, 1998, pp. 19-33 y 47.

${ }^{72}$ Pelayo CATOIRA, Conveniencia de la institución de los municipios en España, I 15.XII.1860, $\mathrm{n}^{\circ} 6$, pp. 93-96 y sigs., que destaca los vínculos interregionales.

${ }^{73}$ A. de la IGLESIA, Los Churruchaos y la torre de la Barreira, VI, 15.XI.1865, $\mathrm{n}^{\circ}$ 21, pp. 337-345.

"CUADERNOS DE ESTUDIOS GALLEGOS", Tomo XLVII, Fascículo 113, Santiago 2000. 
sente sólo en la síntesis de historia local escrita en gallego por A. de la Iglesia $^{74}$.

A los desnudos hechos se atiene también la descripción de monumentos venerables, ya sean los más primitivos o los medievales, mejor conocidos. La descripción arqueológica es siempre un esfuerzo de interpretación que atiende a los datos históricos. Someras referencias al celtismo, caballo de batalla de la generación siguiente, lo señalan como factor histórico ineludible, sin la carga explosiva consiguiente a la polémica finisecular entre germanos y latinos y, por supuesto, todavía sin respaldo de teoría racial alguna ${ }^{75}$.

\section{RESCATE DE LA LENGUA Y CONSAGRACIÓN DE LA LITE- RATURA GALLEGA}

La pretensión de que Galicia entrase en la historia como una reserva de fuerzas frescas y genuinas conlleva la dignificación y codificación de su expresión espontánea, tarea tan vital como la elaboración de su historia, y que sólo podía surgir de los nativos. La restauración patria exigía el acceso a instancias más altas de la voz múltiple y diferenciada de sectores hasta allí mudos y subalternos. Y el habla muestra precisamente el punto de encuentro entre el pueblo iliterato y los escritores que buscan la salvación común integrando en un todo esos dos mundos incomunicados. Ese concepto alternativo de cultura pasa a través de la recuperación del gallego como lengua de creación literaria, faena ingrata dado el abismo que separa a ricos y pobres. La presión lingüística castellanizante en el Reino de Galicia durante toda la Edad Moderna había convertido la lengua local en una modalidad popular y en razón del nulo valor humano de sus hablantes carecía de prestigio cultural por lo que el castellano es uso exclusivo de la gente acomodada y el gallego queda para la clase subalterna o el trato familiar. Tan completa es la aceptación del castellano como lengua culta que hasta en las revistas de la primera toma de conciencia local

\footnotetext{
${ }^{74}$ Antón da IGREXA, Reseña stórica de Galicia, II, 15.IX.1861, n² 24, pp. 369-371.

${ }^{75}$ R. BARROS SIBELO, Costumbres ..., cit.; A. de la IGLESIA, Portugal, III, $1^{\circ}$. IV.1862, nº 7, p. 98; A. da IGREXA, Reseña stórica .... cit., p. 369.
}

"CUADERNOS DE ESTU்DIOS GALLEGOS", Tomo XLVII, Fascículo 113, Santiago 2000. 
el castellano desbanca al gallego: en 1845 «LaAurora de Galicia» relegaba el uso del gallego a una poesía de Añón y otra de Alberto Camino.

Dada la dinámica del conflicto lingüístico es obvio que mejorar de status supone cambiar de lengua y desprenderse de la habitual en los pobretes como quien arroja una prenda indecente ${ }^{76}$. Combatir prejuicios tan arraigados obligó a los iniciadores del rescate de Galicia a usar métodos de catequesis y a enseñar que el idioma, como el folklore, no es pintoresquismo vacuo sino crisol donde se funden los motivos de una peculiar evolución cultural. Al divulgar las razones que asisten su fe en la lengua local siembran ideas que no son en ningún caso mistificaciones ni ilusiones fantásticas. Y practicándola en todos sus registros abren el debate sobre el deber de conservarla. En este aspecto la revista es un semillero de ideas: si empieza por denunciar la criminal desidia hacia el idioma, se aplica también a recogerlo y promueve instrumentos que facilitasen el acceso a su conocimiento. A falta de normalización, cualquiera que fuese, un paso adelante es la publicación del Diccionario de Rodríguez, pionero con todos los defectos del caso ${ }^{77}$ Ciertas incursiones en terreno filológico denotan lo prematuro de tal empeño y la improvisación a que se atenía por entonces la pasión lingüística ${ }^{78}$. Tan incondicional defensa del idioma ca-

${ }^{76}$ «Los gallegos aquí como en Castilla, con muy raras escepciones, parece que reniegan de todas las cosas de su Patria. [...] no adelantarás gran cosa mientras no llegue a arraigarse en el corazón de nuestros gallegos el amor por el suelo que les vio nacer y los sentimientos de su propia dignidad. Todos se envanecen de decir y proclamar su oriundez y las glorias de su patria, ausiliarse y protegerse cuando nosotros hacemos todo lo contrario. Parásito he visto yo en Madrid que a mi presencia llegó a negar ser gallego, y a desatarse en dicterios tales contra este desgraciado país, que a no mediar dos amigos que se hallaban presentes hubiera terminado desastrosamente la contienda, no pudiendo yo sufrir con paciencia tanto cinismo y desvergüenza»: Juan Manuel PINTOS, A gaita gallega tocada po lo gaiteiro, ou sea Carta de Cristus para ir deprendendo a ler, escribir e falar ben a lingua gallega, e ainda mais, Pontevedra, J. y P. Vilas, 1853, pp. 174-175.

${ }^{77}$ Diccionario gallego-castellano, su autor, el Presbitero D. Francisco Javier Rodriguez, ahora difunto, Bibliotecario que fue de la Universidad literaria de Santiago. Dalo a lus la Galicia, Revista Universal de este Reino, bajo la dirección de D. Antonio de la Iglesia y González, Coruña, Imp. del Hospicio Provincial, 1863. V. el anuncio de suscripcción en III, 15.VIII.1862, n ${ }^{\circ}$ 16, pp. 241-242; cfr. José Luis PENSADO, Contribución al estudio de la lexicografia gallega. I. El Diccionario gallego-castellano de F. J. Rodríguez y su repercusión en la lexicografia gallega, Universidad de Salamanca, 1976.

${ }^{78}$ Domingo DÍAZ DE ROBLES, Galicia. Etimología de su nombre, VI, 15.III.1865, $\mathrm{n}^{\circ} 6$, pp. 81-83; id., Etimologías históricas y críticas, VI, $1^{\circ}$.XII.1865, n 23, pp. 359-360.

"CUADERNOS DE ESTUdIOS GALLEGOS", Tomo XLVII, Fascículo 113, Santiago 2000. 
rece de los matices políticos que adquirirá luego, cuando la existencia de una lengua propria se transforme en uno de los principales argumentos a favor de la secesión.

Dando por descontado el prestigio cultural y social del castellano la revista se sirve de él como garantía de difusión a su mensaje pero reserva amplio espacio al gallego. En prosa usa el castellano por su mayor solera ${ }^{79}$ pero paralelamente promueve un corpus poético en los dos idiomas con registros variadísimos. Un perfecto bilingüismo inspira la recuperación de autores locales tan desconocidos como Sarmiento y el jesuita Álvarez Sotelo al lado de otros bien afirmados, desde el Cura de Fruime a Pastor Díaz. Rosalía Castro y los contemporáneos gallegos o portugueses ${ }^{80} \mathrm{se}$ emparejan con el Rey Alfonso de las Cantigas y con los poetas en gallego del Cancionero de Baena, de reciente publicación ${ }^{81}$. Este último hallazgo abre la exploración de terrenos lingüísticos y poéticos que eran hasta allí pura arqueología. Rescatar la poesía medieval no es complacencia erudita que desempolva glorias pretéritas de dudosa utilidad actual sino que significa deshacer añosos tópicos sobre la falta de una literatura en gallego. Junto a las cimas de la cultura alta, los frutos de la musa popular que en nada desdecían de ellas: equiparando así la creatividad popular y anónima con los productos culturales de las clases superiores se afirma el valor de la literatura como instrumento de cohesión capaz de estimular la autoestima, de encender la fantasía y ¿por qué no? de consolar de las amarguras presentes.

Serán precisamente los poetas quienes combatiendo la alienación lingüística de la clase dominante le pongan delante el mundo de los pobres que sólo en gallego se expresaban. Tan entrañable rescate -cívico y artístico a un tiempo- pone en circulación motivos de profundo significado ético -el abismo entre ricos y pobres, la injusticia de las quintas, el dolor de la emigración-que encuentran en el idioma vernáculo su mejor expre-

\footnotetext{
${ }^{79}$ A excepción del cronicón de Don Servando «obispo de Orense y confesor de Don Rodrigo que se halló en la pérdida de España», en versión gallega, y de la Reseña ..., cit.

${ }^{80} \mathrm{Cfr}$. la nutrida serie de artículos de LÓPEZ DE LA VEGA sobre sus manifestaciones cultas y populares: La poesía portuguesa y la poesía gallega, IV, $1^{\circ} . \mathrm{III} .1863, \mathrm{n}^{\circ} 5$, pp. 39-40 y passim.

${ }^{81}$ El Cancionero de Juan Alfonso de Baena. Siglo XV. Ahora por primera vez dado a luz con notas y comentarios [por Pedro José Pidal], Rivadeneyra, Madrid, 1851.
}

"CUADERNOS DE ESTUDIOS GALLEGOS", Tomo XLVII, Fascículo 113, Santiago 2000. 
sión. Ni pocos ni insignificantes fueron los escritores atraídos por el gusto de la imitación popular, de los que la posteridad recuerda principalmente a Rosalía Castro. En ese contexto, y como eco de la boga literaria de la «dolora» ${ }^{82}$ se produce la acuñación del tópico de la Galicia llorosa, de consecuencias y persistencia incalculables, que prevalecerá sobre otros matices igualmente relevantes del alma nacional (como aquel genio alegre tan bien captado por las glosas de Rosalía a las coplas populares ${ }^{83}$. En todos estos casos hay una evidente identificación con el gusto popular, ya fuera gallego o portugués. La continuidad de inspiración es terreno común en el que colaboran el culto al lado del inculto, Rosalía y los anónimos cantores aldeanos. La maduración de una lengua literaria gallega llega a su sazón en esta incomparable reunión de escritores con una amplitud temática que abarca desde la elaboración folklórica al elogio del ferrocarril, desde la inspiración patriótica hasta la artificiosa imitación de la expresión popular, tan del gusto romántico. El corpus poético ofrecido por la revista es campo abierto a una prometedora investigación sobre la persistencia de las fórmulas románticas de poesía colectivizada, encarnación panteística de un Volksgeist idealizado.

Como, por otra parte, identificarse con los valores simbolizados en el mundo campesino significa dotar a la expresión poética de particular engagement, una afectividad extraordinaria impregna la percepción de la existencia de los pobres. Muchas de estas composiciones delatan un cambio de sensibilidad, una mutación en el clima social que capta la existencia rural como problema: así en el caso de la invectiva rosaliana a los castellanos, con su radicalización obvia dada la situación catastrófica, análoga a la inspiración de Juan Manuel Pintos en A gaita gallega, que acentuaba ya la problemática ricos y pobres y la explotación de una clase

\footnotetext{
${ }^{82}$ Cfr. José Luis VARELA, Poesía y restauración cultural de Galicia en el siglo XIX, Madrid, Gredos, 1958, p. 164.

${ }^{83}$ Cfr. Marina MAYORAL, La poesía de Rosalía Castro, Madrid, Gredos, 1974, cap. XVII. Dotada de gran repercusión social, la poesía cívica se brinda en su calidad de anales sociales: v. el problema de las quintas en F. de la IGLESIA, 398. En Rosalía la polémica roza lo político: «Probe Galicia, non debes / Chamarte nunca española / Que Spaña de ti s'olvida / Cando eres jai! tan hermosa [...] / Galicia, ti non tes patria / Ti vives no mundo soia ... (A gaita gallega. Resposta o eminente poeta D. Ventura Ruiz de Aguilera, III, 162; invectivas contra los castellanos, id 192.
}

"CUADERNOS DE ESTUDIOS GALLEGOS", Tomo XLVII, Fascículo 113, Santiago 2000. 
por otra, etc. ${ }^{84}$. Todos esos textos ofrecen a los investigadores del Rexurdimento un fértil campo. En ellos se compendian las fascinantes posibilidades de trabajo literario que seguía ofreciendo la inmersión en la tradición popular, en pos de procedimientos creativos descubiertos por los románticos. El estudio de la vena popular y sus variaciones, el origen de los relatos, las estrategias narrativas, los recursos descriptivos, el contenido ideológico, etc, etc, están ahí brindándose a una detenida investigación. Y lo mismo en lo que se refiere a la experimentación lingüística, con procedimientos que parten de la imitación de la lengua popular o de modelos literarios arcaicos y que se sirven de una artificiosa jerga medieval para crear espacios poéticos intencionalmente remotos ${ }^{85}$. Otro tanto puede decirse de la constante presencia de la poesía narrativa, reelaboración literaria en verso de motivos radicados en la oralidad. El repertorio de temas, de gran amplitud, cede apenas a la tentación de la imaginería céltica, por ahora simple pincelada de color histórico ${ }^{86}$, cuya función combativa será multiplicada en breve por el desencanto político transformándose en ingrediente indispensable para el deleite de los lectores.

No acaba aquí el intento de dar a conocer a los ingenios locales: aspiraciones más altas toman por modelo el fijado por la Academia española en sus ediciones de clásicos si bien la envergadura de la empresa y la exigüidad de recursos indique repliegues más modestos. El itinerario a seguir lo inicia la reseña hispano-portuguesa de López de la Vega que hará fortuna e inspirará sucesivas antologías donde conviven lo individual y lo colectivo, lo erudito y lo popular. En germen está ya ahí El idioma gallego. Su antigüedad y vida que más tarde publicará A. de la Igle$\mathrm{sia}^{87}$, preparado con un rastreo sistemático de manifestaciones lingüísticas gallegas desde los albores hasta el presente. La primera prueba del reconocimiento público de la literatura local la dan los Juegos florales promo-

\footnotetext{
${ }^{84}$ Op. cit., pp. 29-30; aquí armadores vascos y empresarios catalanes protagonizan un vil comercio de esclavos blancos: p. 28.

${ }^{85} \mathrm{~F}$. de la IGLESIA, Romance en castellano antiguo, III, $\mathrm{n}^{\circ} 23,1 . \mathrm{XII} .1862$, p. 368; A. da IGREXA, Reseña stórica..., cit.

${ }^{86}$ «Ou arpas do druida, despertade!/ Erguevos d'entre as cinzas dos meus castros!/ ¡Vinde a cantar un trunfo a nosa edade/ Dos meus pórfidos dino, e os meus labastros!»: F. de la IGLESIA, $A$ Galicia, II, $1^{\circ}$.VIII.1861, nº 21, p. 333.

${ }^{87}$ Latorre y Martínez, La Coruña, 1886.
} 
vidos por GRUR en La Coruña, con declarado mimetismo hacia el ejemplo catalán y éxito rotundo. Las composiciones premiadas se publicaron en el Album de la Caridad, rico volumen antológico así llamado por el empleo a que se destinaba el producto de su venta. Su patrocinador, José Pascual López Cortón es ejemplo, igual que la Condesa de Espoz y Mina, de cómo las ingentes fortunas amasadas en ultramar por la burguesía comercial gallega revertían al cabo en beneficio de la colectividad ${ }^{88}$.

Al llegar aquí es ya evidente cómo la práctica de la literatura se entreteje con el nuevo panorama de la patria. En su raíz se adivina una estrategia que enfrenta a la eterna pasividad de los gallegos una enérgica efervescencia. Aunque minoritario ese talante incita a los vates nacionales a cantar los temas más candentes y a anunciar días de gloria a la patria ${ }^{89}$. Para más, la propensión de GRUR a asomarse fuera del terruño ensancha de modo inesperado el concepto de nación que propugnan sus páginas y deja ver amplitudes ultramarinas. Ya no sólo referida a Galicia sino a la prolongación de la comunidad ibérica al otro lado del Atlántico aparece la transcripción de usos y valores burgueses popularizada bajo el marchamo de costumbrismo, tan caro a los románticos: los relatos de Virginia Felicia Auber, reseña de costumbres contemporáneas cubanas, además de encarnar una hermandad nada ficticia entre las riberas del Atlántico incorporan al discurso histórico, ensalzándola, una moral que es la de las clases dueñas de la situación ${ }^{90}$. Las mismas que al poco «harían patria» de modo muy concreto fundando centros gallegos en ultramar y que acabarían reivindicando la autonomía.

${ }^{88}$ Album de la Caridad. Juegos florales de La Coruña en 1861, seguido de un Mosaico poético de nuestros vates gallegos contemporáneos, Impr. del Hospicio Provincial, La Coruña, 1862; cfr. III, $1^{\circ}$.V.1863, n 9, p. 67; López Cortón, casado con Julia Viqueira (v. correspondencia con A. de la Iglesia en RAG, loc. cit.) se relacionaba con la familia Giner: v. A.S.PORTO UCHA, La Institución Libre de Enseñanza en Galicia, Ed. do Castro, Sada-A Coruña, 1986, passim; los Cortón, originarios de Cedeira, eran banqueros y negociantes en Puerto Rico: cfr. IGyA, III, nº , p. 238.

${ }^{89}$ Francisco de la IGLESIA, O espertador dos cantadores gallegos, III, $\mathrm{n}^{\circ} 12$, 15.VI.1862, p. 179, que remite a Pastor Díaz: cfr. su Discurso de 1846 en el Liceo de La Coruña, I, 15.XI.1860, nº 4, p. 56.

${ }^{90}$ Apuntes biográficos sobre la escritora Felicia, II, 15.XII.1861, n 30, pp. 475-477; cfr. Alfredo de la IGLESIA, Los olvidados, en «Almanaque Gallego de Buenos Aires», 1921; Isabel RUIZ APILANEZ, Ambarina. Estudio crítico de la novela, Xunta de Galicia, 1989.

"CUADERNOS DE ESTUDiOS GALLEGOS", Tomo XLVII, Fascículo 113, Santiago 2000. 


\section{PORTUGAL Y GALICIAA LA LUZ DE LA UNIÓN IBÉRICA}

El rumbo de la revista va de la conciencia de degradación local a la afirmación de Galicia como personalidad complementaria de la totalidad ibérica. Su conciencia de ser una «publicación patriótica» ${ }^{91}$ implica la existencia de España como nación de naciones y suma de diversas colectividades, en una dinámica visión que integra a todos los territorios de la Península y de Ultramar, esto es, lo más distante de cualquier tipo del secesionismo que se pueda imaginar. A la fuerza centrífuga de la insolidaridad, defecto de educación cívica, contrapone un sistema de principios respetuosos de intereses y libertades recíprocas. Integrándose en la corriente que desde unos veinte años antes venía llamando la atención sobre la cuestión portuguesa ${ }^{92}$, GRUR propugna la unión con Portugal, pieza importante en un nuevo sistema dinámico peninsular. El deslumbramiento causado por el modelo de unión italiana tiene su reflejo por estas fechas en la prensa gallega encandilada con el engrandecimiento ante Europa derivado de la unión fraternal de los pueblos ${ }^{93}$. GRUR comulga con los planteamientos de la Unión Ibérica y aboga por la resurrección de una nación galaico-portuguesa, tan debilitada por siglos de separación política como visible a nivel cotidiano. Favorecida por la espontánea comunidad de expresión, la patria ideal ambicionada por la Unión Ibérica surgiría por atracción de voluntades más que de manejos gubernativos. Así lo cree la élite de ambos lados del Miño, ya se tratase de portugueses como el periodista Claudio Adriano da Costa, que veía la recíproca conveniencia de la unión, o de españoles como José López de la Vega en sus editoriales del «Porvenir Hispano Lusitano» ${ }^{94}$. El mensaje iberista alcanza cierta

\footnotetext{
${ }^{91}$ Cfr. el balance de la redacción: Pensamiento de la 'Galicia', VI, $1^{\circ} . \mathrm{I} .1865, \mathrm{n}^{\circ}$ 1, pp. 1-3.

${ }_{92}$ Cfr. María Victoria LÓPEZ CORDÓN, El pensamiento político del federalismo español (1868-1874), Barcelona, 1975, y La política exterior y la España de Ultramar. 1871-74, en Historia de España. M.Pidal, vol. XXXIV, pp. 821-879; Antonio GONZALES, Las ideas federalistas portuguesas, en «Revista de Estudios Políticos», 1970, nº 173.

${ }_{93}$ Cfr. «El Gallego», de Pontevedra, 30.V.1863.

${ }^{94}$ Ligado al proyecto inicial de «La Joven Galicia», acabó considerándose traicionado por sus colegas pero seguía relacionado con Londres y Roma: J. L. de la V. a A. de la I., s.f.: RAG, Donación de la Iglesia, Caja 97. V. las iniciativas unitarias a cargo de Sinibaldo de Mas, Juan Valera y su proyecto de «Revista Ibérica» en 1853: cfr. JOVER, Historia de la civilización..., cit., pp. 181 y 185.
}

"CUADERNOS DE eSTUdios GALLEGOS", Tomo XLVII, Fascículo 113, Santiago 2000. 
popularidad y se ventila constantemente en GRUR que aspira a la abolición de «la barrera aduanera y otras vallas más entre dos naciones llamadas a constituir por naturaleza una sola nacionalidad». Por entonces la «Revista Peninsular» de Lisboa recogía análogas sugestiones. El elogio de Portugal salpicado a lo largo de las páginas de GRUR subraya los numerosos vínculos de sangre, idioma, religión, literatura, geografía y comercio entre Galicia y Portugal. A cargo de Antonio de la Iglesia y más a menudo de José López de la Vega, cualquier acontecimiento cultural da pie a mensajes de fraternidad ỳ simpatía: así el elogio de una compañía dramática portuguesa que acababa de actuar en La Coruña es pretexto para recalcar la incomunicación de Galicia con el resto de España en cuestión de artes y ciencias y la mayor comunicación y resonancia de lo portugués. Razones emotivas, como la ostentación castellana de desprecio hacia la supuesta inferioridad portuguesa, movían también a simpatía hacia los portugueses, «tan celtas como nosotros», y merecedores de una mano amiga porque «su lengua es nuestra lengua, y su raza es nuestra raza y las glorias de Portugal son nuestras glorias» ${ }^{95}$.

Con ese fin la larga serie de artículos de José López de la Vega subraya la común inspiración popular y reseña la existencia de una literatura contemporánea portuguesa tan valiosa como desconocida, igual que sucedía con la gallega ${ }^{96}$. La teoría de la literatura tradicional esbozada por López de la Vega remite a las creaciones individuales perpetuadas por la colectividad en la memoria común. Un mismo vehículo expresivo sirve de hilo conductor a Rosalía Castro y a los contemporáneos portugueses y los hermana con los copleros e improvisadores de las fiestas aldeanas a ambos lados del Miño. Incluso el cariz de la inspiración popular sirve para poner de relieve la comunidad espiritual de gallegos y portugueses. López de la Vega venía batiéndose desde 1858 por la causa portuguesa, cuando redactaba en Vigo un periódico experimental, «El Porvenir hispano-lusitano», significativamente subtitulado «Revista de comercio, industria, ferrocarriles, telégrafos y letras». Su labor atestigua la amplia aceptación del programa de cohesión peninsular que consideraba Portugal como com-

\footnotetext{
${ }^{95}$ A. de la IGLESIA, Portugal, III, $1^{\circ}$. IV.1862, nº 7 , p. 99.

${ }^{96}$ La poesía portuguesa y la poesía gallega, IV, $1^{\circ} . \mathrm{III} .1863$, nº 5 , pp. 39-40; siguen once artículos más.
}

"CUADERNOS DE ESTUDIOS GALLEGOS", Tomo XLVII, Fascículo 113, Santiago 2000. 
plemento natural. La idea de una federación, reforzada en aquel momento con proyectos de unión aduanera y línea férrea Oporto-Vigo, prometía hacer a ambos pueblos ricos y felices ${ }^{97}$, impide considerar visionarios a los hombres de letras que aplican sus dotes y sensibilidad a electrizar los dos países hermanos. Si la función histórica de la utopía es enriquecer la conciencia colectiva ensanchando las posibilidades históricas de un pueblo, a esa misión no podían sustraerse sin traicionar su conciencia patriótica. No cabe duda de la prometedora configuración peninsular esbozada por el federalismo en estos años, muy en consonancia con la transformación cultural de los nuevos tiempos. La declaración de principios estampada al frente del «Porvenir Hispano-Lusitano» sobrevivió al ser recogida por GRUR, donde López de la Vega prosigue en su empeño y donde su concepto de hermandad literaria gallego-portuguesa tiene algo de manifiesto político de eficacia salvadora. Lo curioso es que la convicción de esa identidad cultural lleva a sostener la existencia de una literatura común precisamente en el momento en que las diferencias lingüísticas entre castellano y portugués hacían desmoronarse el proyecto de una literatura ibérica en sentido más amplio ${ }^{98}$.

A estos entusiastas no se les oculta la dificultad de formar un programa sugestivo de vida común, y bien podía serlo la consecución de un tenor de vida elevado. ¿Bastarían esos elementos para unir a Galicia y Portugal en un sistema eficaz? Frente a la insolidaridad o disgregación localista típicamente gallega, no se cansan de subrayar las ventajas del espíritu de asociación que en otras latitudes producía milagros, como enseñaba la admirable lección de Inglaterra, donde el interés individual se convierte en resorte colectivo ${ }^{99}$. Si el sentimiento unitario lograra sobreponerse a las diferencias locales acabaría por fin el interminable compás de espera de la decadencia ibérica. Desde las páginas de GRUR la intelectualidad gallega, como respondiendo a un Que doit-on à la Galice?, profetiza el advenimiento de una era mejor y más justa para el inmediato futuro. $\mathrm{Al}$

${ }^{97}$ «El Porvenir Hispano-Lusitano. Revista de comercio, industria, ferro-carriles, telégrafos y letras», Vigo, Año I, sábado 10.IV.1858, n 1 , p. 3: interesantísimas las conexiones con Prim.

98 Cfr. José Antonio ROCAMORA, El nacionalismo ibérico. 1792-1936, Universidad de Valladolid, 1994, pp. 59.

99 Unión otra vez, V, 15.VI.1864, n 12, pp. 178-180.

"CUADERNOS DE ESTUDIOS GALLEGOS", Tomo XLVII, Fascículo 113, Santiago 2000. 
progreso material y moral de la Península contribuiría de forma decisiva la unión de gallegos y portugueses y su sintonía con América. No es necesario encarecer el significado de esta precoz toma de conciencia que no ve incompatibilidad alguna entre el protagonismo local y la unidad española. ¿Hubiera evitado la configuración iberística el finis Hispaniae? Más allá de hipótesis vacuas lo que interesa subrayar es la inyección de optimismo que por primera vez se les propina a los gallegos desconfiados de su papel en el mundo: GRUR puso de manifiesto los fermentos de vitalidad de una colectividad hasta allí mortecina, demostrando con pruebas irrefutables que Galicia poseía una vida intelectual, científica y artística atenta a lo moderno. Y aunque los efectos de esa actitud no fueran tangibles ni inmediatos, convendrá no perder de vista la coincidencia entre tan esperanzadora visión y la declaración programática del Comité regionalista de La Coruña que, treinta años después, volvía a traer a primer plano el nombre de Francisco de la Iglesia ${ }^{100}$. Pero para entonces nuevas exigencias, precipitándose definitivamente por otros derroteros, reclamaban ya movimientos de masas portadores de reivindicaciones galleguistas. Y esto es harina de otro costal.

\section{SIGLAS}

GRUR $=$ «Galicia. Revista Universal de este Reino»

IGyA $=$ «La Ilustración Gallega y Asturiana»

$\mathrm{RAG}=$ Real Academia Gallega. La Coruña

${ }^{100}$ Cfr. «El Regional», 20.XII.1890.

"CUADERNOS DE ESTUdiOS GALLEGOS", Tomo XLVII, Fascículo 113, Santiago 2000. 